$\begin{array}{lllllllll}\text { A } & \mathrm{R} & \mathrm{T} & \mathrm{Y} & \mathrm{K} & \mathrm{U} & \mathrm{E} & \mathrm{Y}\end{array}$

\title{
Uwagi o znakach własnościowych z drugiej połowy XV i pierwszej ćwierci XVI wieku w inkunabułach Biblioteki Uniwersyteckiej w Poznaniu
}

\begin{abstract}
Streszczenie. Artykuł stanowi zbiór uwag dotyczących charakterystycznych kategorii znaków własnościowych książki, znajdujących się w inkunabułach ze zbiorów Biblioteki Uniwersyteckiej w Poznaniu, osadzonych na tle zjawisk kulturowych późnego średniowiecza i początków renesansu w Europie i w Polsce. Analizie poddane zostały: ekslibris malowany (protoekslibris), rysunkowy model ołtarza z herbem fundatora wklejony do książki jako przedmiot dewocji i prawdopodobnie znak własności, tzw. superekslibris zapięciowy umieszczony na zaczepie zapięcia oprawy, nazwiska właścicieli ksiąg zapisane na okładzinach opraw, herby rysowane na stronach tytułowych. Osobną uwagę poświęcono ekslibrisom graficznym, w tym zwłaszcza unikatowym dziełom związanym z anonimowym bibliofilem herbu Rawicz, oraz ekslibrisom odbijanym bezpośrednio na kartach ksiąg.
\end{abstract}

SŁowA KLUCzowe: ekslibris malowany, protoekslibris, model ołtarza, zapiska (nota) własnościowa, superekslibris zapięciowy - Schließen-Exlibris, libraria, monumentum, herb, ekslibris graficzny, Anonim „L G” herbu Rawicz, Piotr Wedelicjusz z Obornik, prymas Stanisław Karnkowski.

Opublikowany przed 12 laty katalog inkunabułów Biblioteki Uniwersyteckiej w Poznaniu autorstwa Wiesława Wydry dostarcza informacji nie tylko o produkcji drukarskiej i introligatorskiej, ale też o kulturze czytelniczej i bibliofilskiej epoki późnego średniowiecza i wczesnego renesansu1. Materialnymi śladami owej kultury są głównie glosy rękopiśmienne, świadczące o niegdysiejszej lekturze tekstów, jak również rysunki znajdujące się w rozmaitych częściach woluminów. Na tle tekstów naniesionych ręką czytelników i właścicieli ksiąg wyróżniają się zapiski

\footnotetext{
${ }^{1}$ W. Wydra, Katalog inkunabułów Biblioteki Uniwersyteckiej w Poznaniu, Poznań 2002.
} 
(noty) własnościowe, niejednokrotnie z towarzyszącym im znakiem identyfikacyjnym. Ponadto poznańskie paleotypy ozdobione są rysowanymi i graficznymi ekslibrisami, a także specyficznymi formami znaków własnościowych z XV i początku XVI wieku, obrazującymi możliwości w tym zakresie ówczesnych bibliofilów. Pozwalają one na prześledzenie ewolucji sposobów oznaczania własności ksiąg i towarzyszącym temu procesowi przemianom na polu heraldyki, pisma, sztuk zdobniczych, a nawet technik graficznych.

Do typologicznie najstarszych, a zarazem najefektowniejszych znaków własnościowych $\mathrm{w}$ inkunabułowych woluminach należy iluminowany herb wkomponowany w antykwowy inicjał "Q[vem (wyraz wydrukowany w całości wersalikami)]" na pierwszej karcie dzieła Plutarcha, Vitae illustrium virorum, sive Parallelae, Venezia, Nicolaus Jenson, 2 I 1478 (sygn. Inc. 211) (il. 1)². Herb ten należy do nieokreślonego rodu zachodnioeuropejskiego, pieczętującego się złotą krokwią i trzema srebrnymi muszlami w czerwonym polu ze złotą bordiurą (skrajem). Na tarczy o późnogotyckim kroju spoczywa hełm turniejowy w charakterystycznej formie (tzw. żabi pysk), rozpowszechniony w XV-wiecznym płatnerstwie europejskim do około $1500 \mathrm{roku}^{3}$. Zdobi go spleciona chusta w barwach godła ze zwisającymi labrami fleuronowymi, o skromnej, późnogotyckiej formie. Klejnot herbu ukazuje głowę drapieżnego zwierza (wilka?), wyłaniającą się z płomieni i zionącą ogniem. Dostojeństwo herbu wzmagają dwa wspięte lamparty pełniące funkcję heraldycznych trzymaczy. Całość otacza iluminowana litera inicjału w niemal kwadratowej ramce, zaś w narożnikowej partii górnego i wewnętrznego marginesu charakterystyczna floratura z liściastą wicią i kwiatami, której kolorystyka oraz sposób złocenia wskazują na tę samą rękę iluminatora co $\mathrm{w}$ inicjale $\mathrm{z}$ herbem. Opisane motywy heraldyczne i ornamentalne pozwalają na powiązanie dekoracji poznańskiego inkunabułu, a pośrednio też jej właściciela, z kręgiem francuskim lub niderlandzkim ${ }^{4}$. W tych bowiem regionach $\mathrm{w}$ XV wieku zdobył wielką popularność typ iluminowanej bordiury floralnej, w której bujne, zielone i niebieskie liście występują z barwnymi kwiatami o cienkich łodygach, zaś całość kompozycji zamykana jest linearną, cienką ramką

${ }^{2}$ Ibidem, nr kat. 295.

${ }^{3}$ Zob. np. W. Kwaśniewicz, Leksykon dawnego uzbrojenia ochronnego, Warszawa 2005, s. 32, 46, 165, il. nienum.

${ }^{4}$ Hipotezę o francuskim pochodzeniu herbu pierwszy przedstawił Wiesław Wydra (op.cit.).

${ }^{5}$ Zob. np. M. Smeyers, Flemish Miniatures from the 8th to the mid-16th Century, Leuven 1999; B. Miodońska, K. Płonka-Bałus, Puławska kolekcja rękopisów iluminowanych księżnej Izabeli Czartoryskiej, Kraków 2001, nr kat./tabl. 4-6, 14-16. 
Il. 1. Ekslibris malowany (protoekslibris) nieokreślonego szlachcica, Francja? Niderlandy?, około 1500

Źródło: zbiory Biblioteki Uniwersyteckiej w Poznaniu.

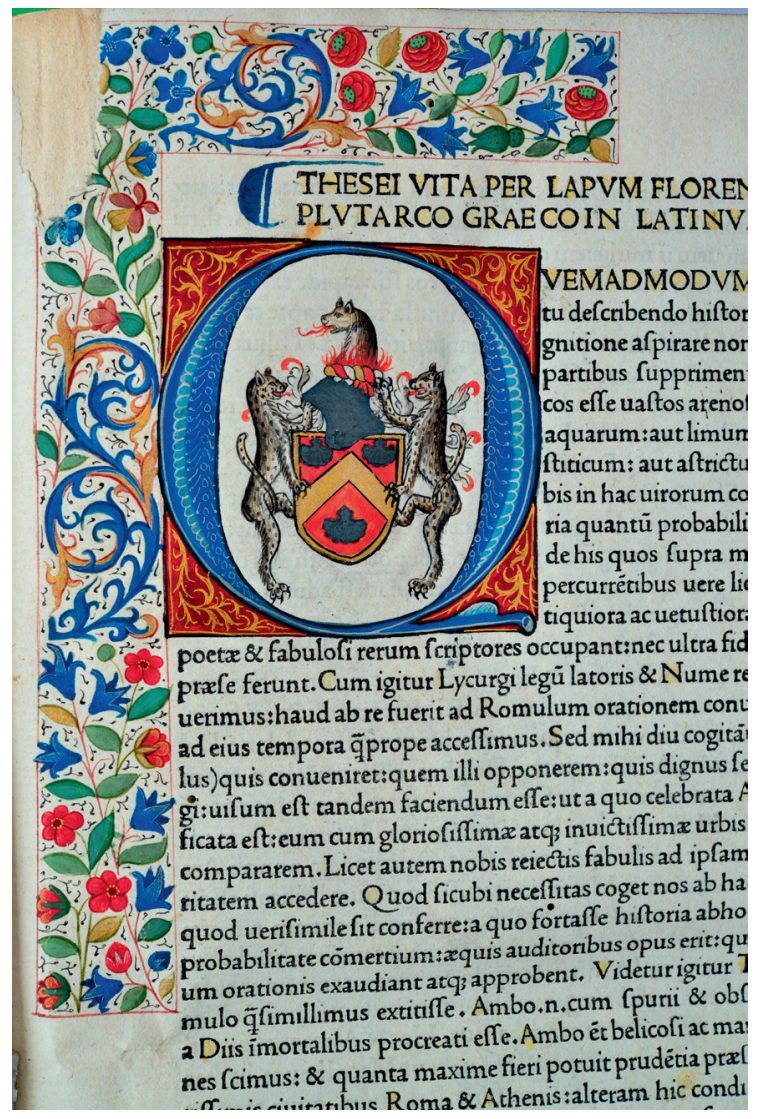

Zwyczaj wkomponowywania iluminowanego herbu właściciela lub fundatora księgi - ekslibrisu malowanego lub protoekslibrisu - na jej pierwszej lub (i) innych kartach cieszył się popularnością w XIV i XV wieku zarówno wśród zachodnioeuropejskich, jak i polskich elit ${ }^{6}$. Nie było to jednak jedyne miejsce jego prezentacji. Powszechnie umieszczano go na dolnych lub bocznych marginesach kart jako samodzielny motyw lub składnik floratur ${ }^{7}$. Niekiedy herb pokaźnych rozmiarów lokowano na wyklejce

${ }^{6}$ Zob. np. Ars scribendi. O sztuce pisania w średniowiecznej Polsce [katalog wystawy], Gniezno 2008, nr kat./il. 70 (herb i wizerunek Mikołaja Słupka, Polska, około 1418); Des livres rares depuis l'invention de l'imprimerie, Sous la direction d'Antoine Coron, Bibliotheque nationale de France 1998, nr kat./il. 3 (herb Petera Knorra, Niemcy, przed 1478).

7 Zob. np. I.F. Walter, N. Wolf, Codices illustres. The world's most famous illuminated manuscripts 400 to 1600, Köln 2005 (herb Bonne de Luxembourg, Francja, 1348-1349); Masterpieces of the J. Paul Getty Museum. Illuminated manuscripts, Los Angeles 1997, nr 25, tabl. na s. 63 (herb papieża Innocentego VII, Włochy, 1404 lub później); J. Obłąk, 
lub na większych, pustych powierzchniach $\operatorname{kart}^{8}$, zaś w luksusowych rękopisach wkomponowywano też w całostronicowe, iluminowane sceny ${ }^{9}$. W przypadku ksiąg przeznaczonych do prywatnego użytku herby takie manifestowały przynależność woluminu do konkretnego księgozbioru, wskazując jednocześnie na pobożność czy też szerokie horyzonty zainteresowań bibliofila. Herby dostojników kościelnych widniejące na kartach ksiąg liturgicznych, takich jak graduały i antyfonarze, były znakami fundacyjnymi, upamiętniającymi kosztowny, a nade wszystko pobożny akt zlecenia wykonania rękopisu ${ }^{10}$. Wraz z rozwojem kultury czytelniczej i postaw bibliofilskich wśród coraz szerszych kręgów szlacheckich i mieszczańskich humanistycznej Italii iluminowane herby przeniknęły do rękopisów i iluminowanych inkunabułów zawierających renesansową dekorację ${ }^{11}$. Odtąd forma herbów i ich dekoracyjnego otoczenia wyraźnie się zmieniła, pozostały natomiast funkcje informacyjne. Dowodem trwałości tej tradycji stały się pod koniec XV wieku włoskie (zwłaszcza weneckie) druki, w których drzeworytnicze obramienia pierwszych stron tekstu zawierały puste tarcze herbowe lub pola otoczone wieńcem,

Z. Jaroszewicz-Pieresławcew, J. Wojtkowski, Katalog inkunabułów Biblioteki Wyższego Seminarium Duchownego Metropolii Warmińskiej "Hosianum” w Olsztynie, Olsztyn 2007, nr kat. 210, tabl. 1 (herb Łukasza Watzenrodego, Polska?, prawdopodobnie lata 70. XV wieku); Kostbarkeiten der Deutschen Staatsbibliothek, Leipzig 1986, il. 76 (herby i wizerunek opatki zakonnej, Niemcy, lata 80. XV wieku); J. Tondel, Inkunabuty w zbiorach Biblioteki Wyższego Seminarium Duchownego w Pelplinie, Toruń-Pelplin 2008, il. na s. 76, tabl. XII (herb i hipotetyczny wizerunek biskupa Stefana z Nidzicy, Prusy Krzyżackie, przed 1495).

8 Zob. np. Ars scribendi..., nr kat./il. 69 (herb i napis fundacyjny biskupa Jarosława Bogorii Skotnickiego, Polska, przed 1373); O. Vanselow, Alte ostpreußische Exlibris, "Zeitschrift für Bücherfreunde" 1935, t. 8, s. 176-177, il. 2 (herb Thomasa Bowtawa, Warmia?, przed 1465), J. Picha, J. Sztuchlik, K. Szelong, Ksią̇nica Cieszyńska, Cieszyn 1995, tabl. III (kompozycja z herbami Hynka Běrky z Násilé, Czechy, około 1483); A. Lewicka-Kamińska, Nieznane ekslibrisy polskie XVI wieku w Bibliotece Jagiellońskiej, Kraków 1974, s. 8-9, il. na frontyspisie (herb i banderola z zapiską własnościową Andrzeja Rudowskiego, Kraków, koniec XV wieku).

9 Zob. np. Trésors de la Bibliothèque nationale de France, t. 1, red. M.H. Tesnière, Paris 1996, s. 120-121, il. nienum. (herb króla Francji Karola VIII, Francja, 1488-1489).

${ }^{10}$ Zob. np. J. Pietrusiński, Graduat prymasa Easkiego w Bibliotece im. Lenina w Moskwie, w: Renesans. Sztuka i ideologia, Warszawa 1976, il. 2, 6-9, 11, 43-47 (herby prymasa Jana Łaskiego, Kraków, około 1520).

11 Zob. np. M. Salmi, La miniatura italiana, Milano 1956, tabl. XLVII, LI/b, LXX/b; C. de Hammel, Manoscritti Miniati, Milano 1987, il. 241b, 242; zob. też omówienie problemu w: A. Wagner, Nieznana oprawa dla Jana Łaskiego w Bibliotece Uniwersyteckiej w Poznaniu. Przyczynek do badań nad italianizmem w introligatorstwie polskim XVI wieku, „Biblioteka” 2012, nr 16 (25), s. 34, il. 5. 
przeznaczone do wkomponowania herbu lub gmerku nabywcy księgi ${ }^{12}$. Stopniowo jednak ten sposób oznaczania własności księgi był wypierany przez formy mniej kosztowne, bardziej praktyczne i modniejsze, czemu towarzyszył proces zamierania sztuki iluminatorskiej.

Niezwykle interesującym i zarazem dość zagadkowym dziełem jest późnogotycki rysunek kolorowany o wymiarach $182 \times 241 \mathrm{~mm}$, przedstawiający tryptyk ołtarzowy z Madonną Apokaliptyczną (w głównej kwaterze retabulum), św. św. Barbarą i Katarzyną (w kwaterach bocznych) oraz zapewne dwoma prorokami (w ażurowym szczycie) (il. 2a). Został on wklejony na wewnętrzną stronę przedniej okładziny dzieła Bernarda de Bustisa, Mariale - Officium et missa Immaculatae Conceptionis Beatae Mariae Virginis, Strassburg, Martinus Flach, 26 VII 1496 (sygn. Inc. 199) (13 $^{13}$ zajął niemal całą jej powierzchnię i zasłonił wcześniejszy wpis (zarys jego liter wyłania się spod górnej części rysunku). Pierwotnie dzieło to było najprawdopodobniej rysunkowym modelem planowanego ołtarza z malowanymi lub rzeźbionymi kwaterami oraz snycerskim zwieńczeniem, przedłożonym jego fundatorowi przez wykonawcę celem zatwierdzenia i wprowadzenia ewentualnych poprawek ${ }^{14}$. W poziomą listwę ramy retabulum wpisane zostały objaśnienia ikonograficzne, zaś w lewy dolny róg głównego przedstawienia herb fundatora ukazujący półksiężyc i sześcioramienną gwiazdę, jak również ledwo widoczny napis „,d[omi]no Joh[anno]" lub „d[omi]n[us] Joh[annes]” (il. 2b). Takie rozwiązanie wpisywało się $\mathrm{w}$ powszechną praktykę upamiętniania fundacji obrazów i ołtarzy w epoce późnogotyckiej, reprezentowaną między innymi zachowanymi do dziś zabytkami polskimi ${ }^{15}$.

${ }^{12}$ Zob. np. J. Picha, J. Sztuchlik, K. Szelong, op.cit., tabl. X (iluminowany protoekslibris biskupa Jana Turzona, Śląsk, 1506); A. Wagner, Nieznana oprawa..., s. 34, il. 6 (rysowane godło i inicjały Sebastiana lub Stanisława Lubomirskiego, Polska, pierwsza połowa XVI wieku).

${ }^{13}$ K. Krzak, Zagadka tryptykowego obrazka znalezionego w inkunabule, „Biblioteka” 1998, nr 2 (11), s. 55-60, il. nienum.; W. Wydra, op.cit., nr kat. 94.

${ }^{14}$ Innymi późnogotyckimi dziełami tego typu w zbiorach polskich są: projekt ołtarza do katedry w Augsburgu (Hans Holbein starszy, przed 1508) i projekt prawdopodobnie rzeźbiarskiego tryptyku (anonim ze szkoły nadreńskiej, XV/XVI wiek), por. Rysunki szkót obcych w zbiorach polskich, Warszawa 1976, nr kat./il. 18; Master European Drawings from Polish Collections, red. A. Kozak, M. Monkiewicz, współpraca T. Sulerzyska, Washington 1993, nr kat./il. 37. Problem organizacji produkcji ołtarzy szafiastych w epoce średniowiecza - por. m.in.: C. Limentani-Virdis, M. Pietrogiovanna, Arcydzieła malarstwa ołtarzowego, przeł. T. Łozińska, H. Borkowska, Warszawa 2004, s. 23-28.

15 Zob. np. J. Gadomski, Gotyckie malarstwo tablicowe Małopolski 1500-1540, Warszawa-Kraków 1995, il. 2-3, 22, 106-107, 230 (wizerunki samych herbów) oraz tabl. III-IV, XIII, XVIII, il. 225, 227, 229, 230-237 i inne (wizerunki herbów i fundatorów). 


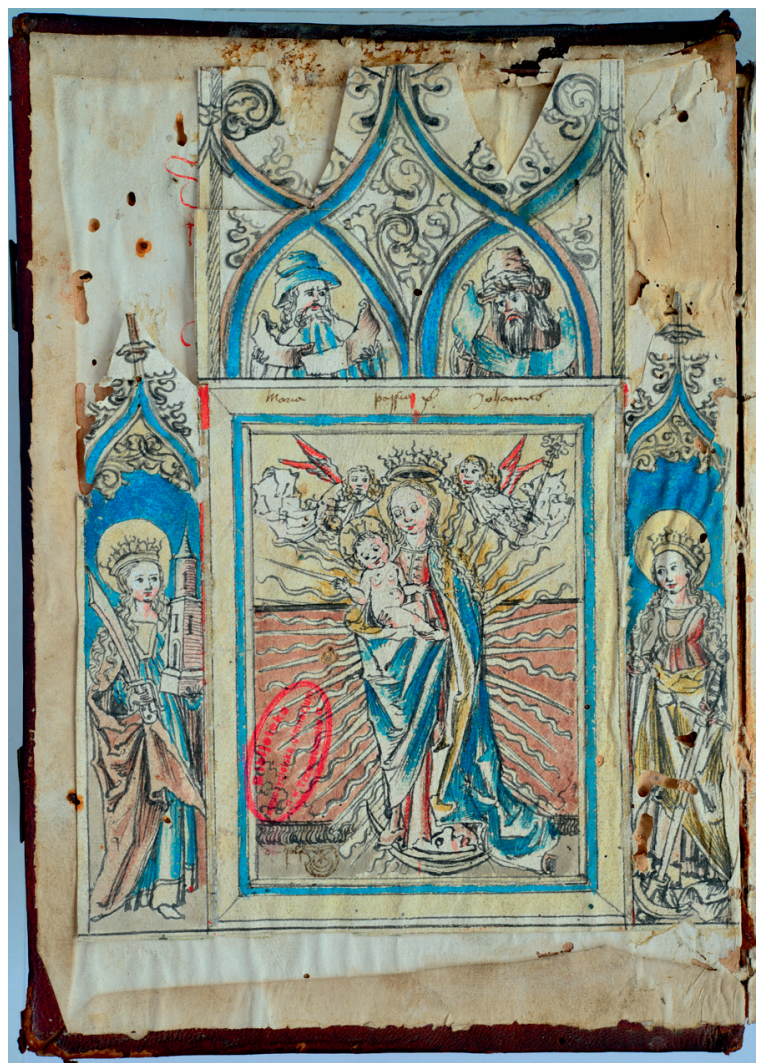

Il. 2a. Rysunkowy model oftarza szafiastego wklejony na wyklejkę inkunabułu, artysta anonimowy, Polska?, około 1500 Źródło: zbiory Biblioteki Uniwersyteckiej w Poznaniu.

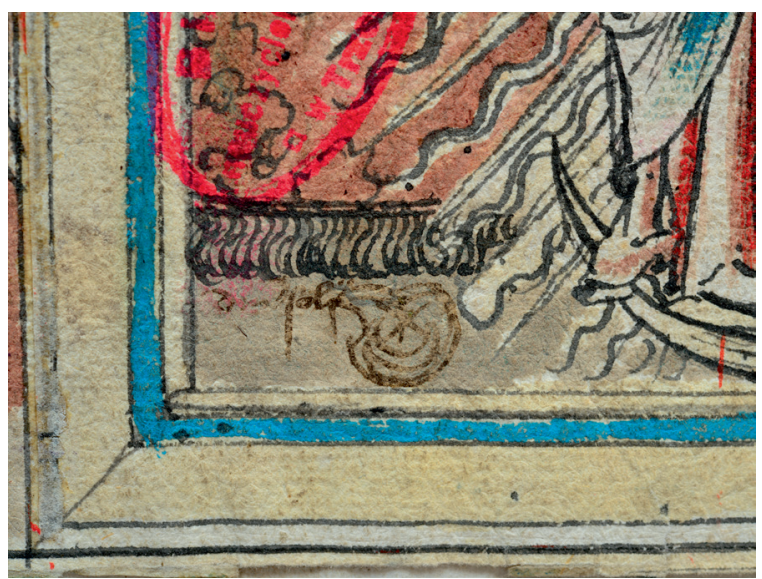

Il. 2b. Rysunkowy model ołtarza szafiastego wklejony na wyklejkę inkunabułu (fragment) 
Z bibliologicznego punktu widzenia istotniejsze jest jednak wklejenie religijnego przedstawienia do wnętrza książki, zjawisko nierzadkie wśród XV-i XVI-wiecznych bibliofilów. Jak dowodzą zachowane do dziś woluminy, na wewnętrzną część przedniej bądź (a także) tylnej okładziny, ewentualnie na wyklejki i inne części książek wklejali oni święte obrazki, zazwyczaj tożsame z rycinami nabywanymi na odpustach i jarmarkach ${ }^{16}$. W przypadku omawianego dzieła uprawniona wydaje się teza o zindywidualizowanej i pozaliturgicznej religijności właściciela inkunabułu, wyrażającej się potrzebą bliskości świętych wizerunków podczas lektury oraz dążeniem do upiększenia woluminu ${ }^{17}$. Jeśli przyjmiemy ponadto, że mógł być on zarazem fundatorem ołtarza, rysunek potwierdzałby własność woluminu za sprawą ukazanego na nim herbu i imienia. Przypomina to przypadek jednego z inkunabułów w Bibliotece Wyższego Seminarium Duchownego w Pelplinie. Na wewnętrznej stronie górnej okładziny wklejono tzw. grafikę śrutową z XV wieku, z wypisanym piórem herbem i nazwiskiem właściciela księgi ${ }^{18}$. Rozbieżność dat powstania grafiki i życia upamiętnionej postaci sygnalizuje jednak, że napis i rysunek naniósł w późniejszym czasie któryś z kolejnych posiadaczy woluminu.

Kim zatem mógł być ów właściciel księgi (a być może i fundator ołtarza), którego herb widnieje na rysunku? Katarzyna Krzak w komunikacie dotyczącym rysunku połączyła właściciela z Andrzejem Drzążyńskim,

${ }^{16}$ Por. m.in. P. Schmidt, Das vielfältige Bild: Die Anfänge des Mediums Druckgraphik, zwischen alten Thesen und neuen Zugängen, w: P. Parschall, R. Schoch, Die Anfänge der europäischen Druckgraphik. Holzschnitte des 15. Jahrhunderts und ihr Gebrauch, Nürnberg 2005, s. 39-52, nr kat./il. 22, 33, 49, 51, 72, 77 i inne. Kilka XV-wiecznych grafik dewocyjnych wklejonych do ksiąg z polskich zbiorów zob. np. w: W. Deluga, Fifteenth-century Prints in Polish Collections, "Print Quarterly” 1995, t. 12, nr 1, s. 39-40, il. 37-39. Przykład iluminowanego wizerunku świętej z XIII wieku wklejonego na przednią wyklejkę późnogotyckiej oprawy zob. w: Rosenkränze und Seelengärten. Bildung und Frömmigkeit in niedersächsischen Frauenklöstern, red. B.J. Kruse, Wolfenbüttel 2013, nr kat. IV. 4, il. 136.

17 O religijnych i estetycznych determinantach wklejania do ksiag rycin dewocyjnych zob. m.in.: I. Fleischmann, Metallschnitt und Teigdruck. Technik und Entstechung zur Zeit des frühen Buchdrucks, Mainz 1998, s. 51-64; S. Brakensiek, Vom „Theatrum mundi" zum "Cabinet des Estampes". Das Sammeln von Druckgraphik in Deutschland 1564-1821, Hildesheim-Zürich-New York 2003, s. 274-275, il. 47.

${ }^{18}$ J. Tondel, op.cit., s. 83-86, il. na s. 84-85; A. Wagner, Ryciny śrutowe z Biblioteki Wyższego Seminaium Duchownego w Pelplinie. Unikatowe dzieła grafiki piętnastowiecznej, w: Visibilia et invisibilia w sztuce średniowiecza. Księga poświęcona pamięci Profesor Kingi Szczepkowskiej-Naliwajek, red. A. Badach, M. Janiszewska, M. Tarkowska, Warszawa 2009, s. 359-368, il. 2. 
wzmiankowanym w 1504 roku jako opat trzemeszeńskiego klasztoru kanoników regularnych. Skłoniły ją do tego zapiski z pierwszej karty tekstu i wewnętrznej strony przedniej okładziny (pod rysunkiem): „[...] Liber fratri Andree dilectus” i „Domina mea Maria ora pro indigno servo tuo Andrea" oraz zapiska datowana na XVII-XVIII wiek, z której wynika, że księga znajdowała się we wspomnianym klasztorze. Rysunek badaczka przypisała artystycznemu środowisku Krakowa z początku XVI wieku, za czym przemawiać miały: jego zgodność „z aktualnymi tendencjami w sztuce”, zamieszczenie herbu Leliwa, „którym posługiwały się rody małopolskie", oraz między innymi motywy Matki Boskiej Apokaliptycznej, aniołów podtrzymujących koronę, czy też drobniejsze detale kompozycyjne ${ }^{19}$. Z kolei w katalogu inkunabułów uniwersyteckich Wiesław Wydra przytoczył treść zapisek własnościowych, ostrożnie atrybuując rysunek wspomnianemu Andrzejowi, jako zakonnikowi trzemeszeńskiemu ${ }^{20}$.

Nie wdając się $\mathrm{w}$ polemikę z zaprezentowanymi hipotezami w zakresie historii sztuki, podkreślić należy jedynie ich dyskusyjność w sferze historycznej i heraldyczno-genealogicznej. Przede wszystkim bowiem nie ma pewności, czy lakoniczne zapiski z początku XVI wieku wymieniające Andreasa dotyczą żyjącego w tym czasie opata trzemeszeńskiego. Bezsprzeczny jest jedynie fakt, że ów „frater" był właścicielem księgi i szczególną atencją darzył postać Maryi, co mogło go skłonić do wzbogacenia napisu okazałym rysunkiem. Zapiskę potwierdzającą znajdowanie się woluminu $\mathrm{w}$ Trzemesznie naniesiono jedno lub dwa stulecia po pierwszym udokumentowanym właścicielu księgi, co nie wyklucza faktu, że od początku XVI wieku mogła ich wielokrotnie zmieniać. Wątpliwości co do włączenia opackiej własności do librarii klasztornej może też budzić brak zapiski donacyjnej tudzież testamentowej, zwyczajowo sporządzanej w podobnych okolicznościach. Ponadto, zakładając, że herb ukazany na rysunku to polska Leliwa, należy wykluczyć opata Drzążyńskiego jako jego nosiciela, ponieważ rodu o tym nazwisku brak wśród Leliwitów ${ }^{21}$, zaś pominięty przez badaczy napis, który widnieje obok motywu tarczy, mówi o nieokreślonym Johannie vel Johannesie. Tym samym posiadanie księgi krótko po jej wydrukowaniu przez trzemeszeńskiego opata pozostawić należy w sferze hipotez, a jego bezpośredni, autorski bądź fundatorski związek z projektem ołtarza uznać za niemal niemożliwy.

${ }^{19}$ K. Krzak, op.cit., s. 58-59.

${ }^{20}$ W. Wydra, op.cit., nr kat. 94.

${ }^{21}$ Lista rodów pieczętujących się Leliwą - zob. np. A. Kulikowski, Wielki herbarz rodów polskich, Warszawa 2005, s. 336-337. 
Źródłem wątpliwości jest zresztą kwestia polskości, a tym bardziej małopolskości herbu ukazanego na rysunku. Wbrew pozorom trudna okazuje się też jego identyfikacja, mimo dość wyraźnie wyrysowanego godła. W obliczu silnego wpływu ciał niebieskich na średniowieczną heraldykę europejską sześcioramienna gwiazda nad półksiężycem była bowiem popularnym godłem, występującym obok polskiej Leliwy między innymi w herbach śląskich polskiego pochodzenia (np. Kyselowský z Kyselova i Granowski vel Granowitz) i czeskich (np. Bezdědicky z Bezdědic, Jan ze Stěnic) ${ }^{22}$. Na obce, może niemieckie pochodzenie posiadacza herbu zdaje się też wskazywać treść napisu z wymienionym imieniem. Charakterystyczny, asymetryczny kształt tarczy z głęboko wciętą pobocznicą oraz cechy formalno-stylowe rysunku prowadzą do wniosku, że żył on pomiędzy drugą połową XV a początkiem XVI wieku' ${ }^{23}$. Mając zatem na uwadze niejasności związane zarówno z początkowymi losami księgi, jak też z fundatorem ołtarza, którego herb i imię widnieje na rysunku, dopuścić należałoby dwie alternatywne możliwości. Pierwsza - księga około 1500 roku należała do niezidentyfikowanego brata zakonnego Andreasa lub do opata trzemeszeńskiego Andrzeja Drzążyńskiego, który wkleił do niej święty obrazek, należący wcześniej do bliżej nieokreślonego Johanna (Joannesa) lub Jana pieczętującego się Leliwą bądź podobnym herbem obcym. Drugą zaś jest przejście Andreasowej lub Andrzejowej księgi w ręce Johanna, Johannesa lub Jana, który będąc fundatorem maryjnego ołtarza, ozdobił ją jego rysunkowym modelem. W takim wypadku herb znajdujący się w obrębie kompozycji upamiętniałby pobożny akt bibliofila, jak też pełniłby funkcję znaku potwierdzającego własność księgi.

Do rzadkości w zbiorach europejskich należą książkowe znaki własnościowe z epoki późnogotyckiej, wygrawerowane na mosiężnych zapięciach opraw, zwane w literaturze niemieckiej Schließen-Exlibris ${ }^{24}$. Owe

22 Zagadnienie motywu gwiazdy i księżyca w heraldyce europejskiej - por. m.in.: P. Dudziński, Alfabet heraldyczny, Warszawa 1997, s. 216-217, il. 566a-i; A. Kulikowski, op.cit., s. 109-116, il. nienum. Zob. też: O. Neubecker, Großes Wappen-Bilder-Lexikon, Augsburg 1995, tabl. na s. 50-51; A. Sedláček, Atlasy erbu a pečetí české a moravské středověké šlechty, Svazek 2, Atlas erbů. Čechy (1. část), Praha 2001, s. 351, il. nienum.; R. Sękowski, Herbarz szlachty śląskiej, t. 2, Katowice 2003, s. 412-413, il. nienum.; t. 3, Katowice 2003, s. 353-354, il. nienum.

${ }^{23} \mathrm{O}$ tym typie tarczy w rodzimej heraldyce XV wieku zob. P. Mrozowski, O sztuce i stylizacji heraldycznej w Polsce XIV-XV wieku, „Rocznik Polskiego Towarzystwa Heraldycznego, nowej serii" 1993, t. 1 (12), s. 86-88, tabl. V, il. 5-7.

${ }^{24}$ G. Adler, Handbuch Buchverschluss und Buchbeschlag, Wiesbaden 2010, s. 96-98; C. Chamrad, Abgerollt und eingeprägt. Rostocker Bucheinbände im 15. und 16. Jahrhundert, „Einband Forschung” 2013, z. 32, s. 84-85, il. nienum. [4]. 
„ekslibrisy zapięciowe”, które z racji ulokowania na zewnętrznej części woluminów winny być uznane raczej za specyficzną formę superekslibrisów (superekslibrisy zapięciowe), stosowano niemal wyłącznie w Rostoku pomiędzy latami 80. XV wieku a latami 20. XVI wieku ${ }^{25}$. Wówczas to kilku introligatorów związanych z lokalnym uniwersytetem wyspecjalizowało się w rytowaniu nazwisk prywatnych właścicieli ksiąg bądź nazw instytucji na zewnętrznych powierzchniach zaczepów i zapinek okładzinowych. Miały one zazwyczaj charakterystyczną formę nawiązującą do wachlarza z piór.

$\mathrm{Na}$ oprawie klocka inkunabułów wydrukowanych między 1498 a 1500 rokiem w Strasburgu i Wenecji (sygn. Inc. 222-224) ${ }^{26}$ znajduje się właśnie taki zaczep wraz z zapinka, spajający dolną część okładzin woluminu (górny zaczep nie zachował się). Na jego prostokątnym trzonie o fazowanych krawędziach i wachlarzowym zakończeniu wyryte jest nazwisko właściciela księgi, "Wulff", dotychczas identyfikowane z nazwiskiem introligatora (il. 3) ${ }^{27}$. Litery napisu odznaczają się prostym, teksturowym krojem, reprezentującym ten sam typ pisma co w znanych zabytkach ze zbiorów niemieckich. Szczegóły opracowania zaczepu, w tym zwłaszcza płytko i linearnie opracowane motywy piór, okrągła perforacja wyzbyta dodatkowych zdobień oraz sznurowy (obecnie ledwo widoczny) ornament pozwalają widzieć w nim wyrób warsztatu rostockiego „Universitätsbuchbindera” lub „Archivmeistera”, działających od schyłku XV do pierwszej połowy XVI wieku ${ }^{28}$. Kwestią otwartą pozostaje jednak ustalenie wykonawcy zapięć, zgodnie bowiem z ówczesną niemiecką praktyką okucia, szczególnie te o bogatszej formie, były wytworem wyspecjalizowanych rzemieślników - okuciowników (niem. Klausurmachern ${ }^{29}$, introligatorowi zatem pozostawało wyrycie na nich nazwiska własnego klienta.

Najprawdopodobniej na górnym, niezachowanym zaczepie wyryte było imię właściciela księgi. Warto jednak zaznaczyć, że w innych tego typu zabytkach pierwsze słowa napisu znajdują się zazwyczaj na zapince,

${ }^{25}$ G. Adler, op.cit.

${ }^{26}$ Według W. Wydry (op.cit., nr kat. 184, 334, 358): Horacy, Opera [...], Strassburg, Ioannes Grüninger, 12 III 1498; Terencjusz, Comoediae, cum directorio vocabulorum [...], Strassburg, Ioannes Grüninger, 11 II 1499; Laurentius Valla, Elegantiae linguae Latinae [...], Venezia, Manfredus de Bonellis et Georgius de Rusconibus, 1 I 1500.

${ }^{27}$ W. Wydra, op.cit., nr kat. 358.

${ }^{28}$ G. Adler, op.cit., s. 97, il. 5-45; C. Chamrad, op.cit.

${ }^{29}$ G. Adler, op.cit., s. 54-59; zob. też moją recenzję tej publikacji w „Kwartalniku Historii Kultury Materialnej" 2012, nr 3, s. 512. 


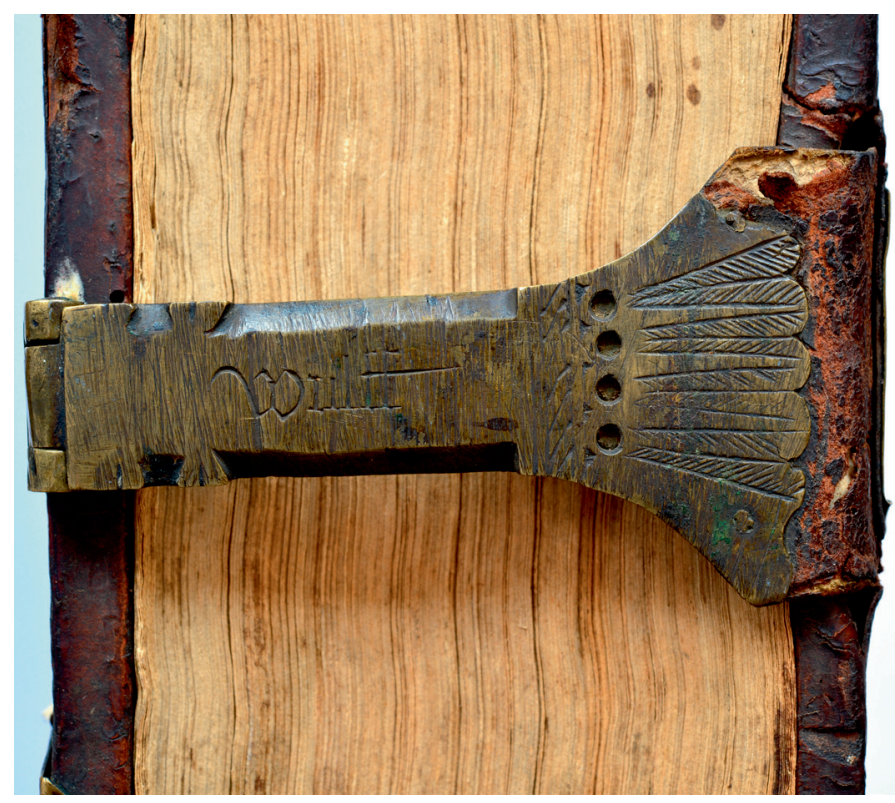

Il. 3. Superekslibris zapięciowy (Schließen-Exlibris) z nazwiskiem „Wulff”, Universitätsbuchbinder lub Archivmeister, Rostok, początek XVI wieku

Źródło: zbiory Biblioteki Uniwersyteckiej w Poznaniu.

która w zamkniętej księdze styka się z zaczepem ${ }^{30}$. W takim wypadku cały napis umieszczony był w jednej linii. Koncepcja zastosowana w poznańskim woluminie wydaje się jednak bardziej praktyczna. Uwzględniając bowiem jeden z najczęstszych sposobów przechowywania ksiąg w librariach późnośredniowiecznych i renesansowych - czyli na leżąco lub stojąco, ale dłuższym (lub jednym z krótszych) obcięciem bloku książki na zewnątrz - możliwa była pełna identyfikacja właściciela księgi stojącej obok innych woluminów bądź leżącej pod lub nad nimi. Dekoracyjna forma zaczepów wespół z wyrazistą barwą i połyskiem mosiądzu uwydatniały zagłębienia rytowanego napisu i przyciągały uwagę walorami estetycznymi.

Na dwóch oprawach inkunabułów ze zbiorów uniwersyteckich widnieją odręczne zapiski, z których przynajmniej jedna może być rozważana jako niewątpliwy znak własności.

Pierwsza z nich znajduje się na skromnej, pergaminowej oprawie inkunabułu Joannesa Arculanusa, Expositio in primam fen quarti Canonis Avicennae [...], Ferrara, Andreas Belfortis, 24 I 1489 (sygn. Inc. 181), wykonanej

${ }^{30}$ G. Adler, op.cit., il. 5-42b, 5-44-5-46. 


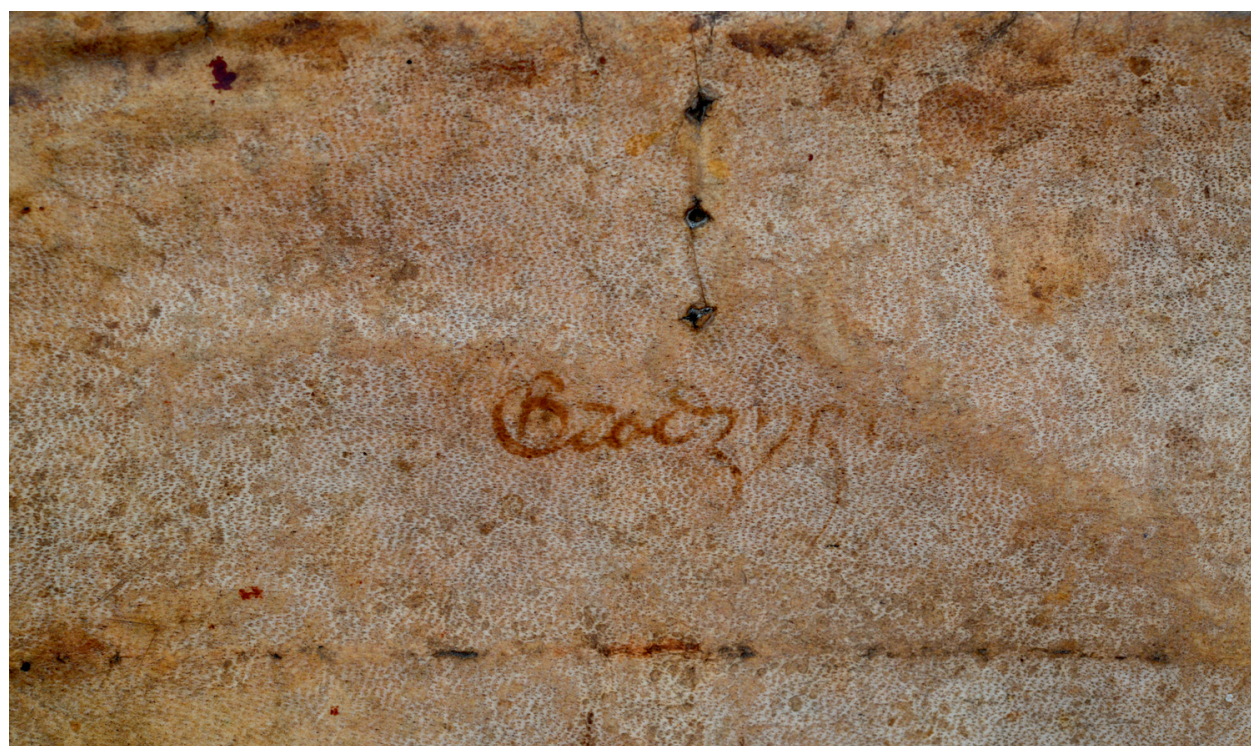

Il. 4. Zapiska własnościowa „Grodzyczky” na oprawie inkunabułu, Poznań?, około 1500 Źródło: zbiory Biblioteki Uniwersyteckiej w Poznaniu.

przypuszczalnie około 1500 roku (il. 4) ${ }^{31}$. Na jej górnej okładzinie dostrzegalne są - dziś już silnie wyblakłe - napisy. Centralny prezentuje tytuł dzieła w majuskułowym, antykwowym liternictwie. Powyżej niego widnieje współczesny drukowi, krótki napis o trudnej do odczytania treści, mogącej stanowić zwięzłe objaśnienie lub komentarz do zawartości księgi. Pośrodku górnej części okładziny znalazł się zaś napis o gotyckim kroju liter: „Grodzyczky”. Niemożność sensownego powiązania tego wyrazu z treścią książki pozwala na uznanie go za nazwisko jej pierwotnego właściciela (a przynajmniej jednego z najwcześniejszych), za czym przemawia zapiska zdradzająca rękę przywykłą do gotyckiego duktu. Kim był ów posiadacz woluminu, trudno dziś rozstrzygnąć. Być może był nim Piotr z Grodziska, wikariusz poznański, o którym wiadomo, że w końcu XV wieku przekazał swe księgi kapitule poznańskiej ${ }^{32}$. Niewykluczone, że chodzi tu o bibliofilów Macieja Grodzickiego (zm. 1517) lub Andrzeja Grodzickiego (zm. 1550), kanoników poznańskich i gnieźnieńskich oraz

${ }^{31}$ Według W. Wydry, op.cit., nr kat. 26.

${ }^{32}$ M. Wojciechowska, Z dziejów ksią̇ki w Poznaniu w XVI wieku, Poznań 1927, s. 93-94; J. Wiesiołowski, Społeczeństwo i książka w późnośredniowiecznym mieście polskim. Poznań i jego osiedla przedmiejskie w XV i na początku XVI wieku, "Studia Źródłoznawcze" 1978, t. 23, s. 68. 
medyków ${ }^{33}$. Mniej prawdopodobne wydaje się zaś, by był to Stanisław z Grodziska (Stanislaus de Grodzisko), żyjący przypuszczalnie około połowy XVI wieku. Z nim związane są: klocek inkunabułów w skórzanej oprawie renesansowej z wyciśniętym superekslibrisem napisowym, przechowywany obecnie w Bibliotece Wyższego Seminarium Duchownego we Włocławku ${ }^{34}$, jak również druki XVI-wieczne włączone do zbiorów Biblioteki Jagiellońskiej ${ }^{35}$. Zakładając, że do którejś z wymienionych postaci należał wybór formy oprawy nabytego druku, oczywisty staje się jej praktyczny, a nie bibliofilski stosunek do książki. Dowodem na to jest ograniczenie się do skromnego materiału oprawy, rezygnacja ze zdobień oraz najprostszy sposób zaznaczenia własności księgi. Warto jednak nadmienić, że mimo rozwijających się postaw humanistycznych w Polsce, w tym zwłaszcza w Krakowie, u schyłku XV i na początku XVI wieku bibliofilskie podejście do książki wciąż stanowiło rzadkość. Zjawisko to zdaje się egzemplifikować słynny uczony Maciej z Miechowa (zm. 1523), który mimo obracania się w kręgach humanistycznej elity skupionej na Akademii Krakowskiej oraz wokół króla Zygmunta Starego nie przywiązywał większej wagi do opraw posiadanych ksiąg, a już tym bardziej ozdabiania ich znakami własnościowymi ${ }^{36}$. Miał on w swym księgozbiorze przynajmniej jedną księgę opatrzoną odręcznym napisem własnościowym na oprawie ${ }^{37}$.

Innym przykładem odręcznego znaku własnościowego naniesionego bezpośrednio na półskórkowej oprawie jest dzieło Marcusa Annaeusa Lucanusa, Pharsalia [...], Venezia, Simon Bevilaqua, 31 I 1493 (sygn. Inc. $253)^{38}$. Na jego dolnej okładzinie, w górnej części deski, zapisane jest pió-

${ }^{33}$ A. Ochmańska, Księgozbiór i zainteresowania bibliofilskie biskupa poznańskiego Jana Lubrańskiego, „Biblioteka” 2001, nr 5 (14), s. 8, przypis 5.

${ }^{34}$ Augustinus Aurelius: De civitate Dei cum commentario Thomae Waleys et Nicolai Trivet, Freiburg i.Br., [Kilianus Fischer], 1494; adl.: Ioannes Ferrariensis: De coelesti vita et de animarum immortalitate. Ed. Antonius de Cauchorio, Venezia, Matth. Capcasa pro Hier. Blondo, 1494; sygn. B WSD Włocławek: XV.F.978-79. Za informację dziękuję dyrektorowi tej placówki, ks. Kazimierzowi Rulce.

${ }^{35}$ Katalog poloników XVI wieku Biblioteki Jagiellońskiej, t. 1, red. M. Malicki, E. Zwinogrodzka, Warszawa-Kraków 1992, nr kat. 891; t. 2, Kraków 1995, nr kat. 1751.

${ }^{36}$ L. Hajdukiewicz, Biblioteka Macieja z Miechowa, Wrocław 1960, s. 86-87, 102; idem, Zainteresowania naukowe Macieja z Miechowa w świetle jego ksiegozbioru, w: Maciej z Miechowa 1457-1523. Historyk, geograf, lekarz, organizator nauki, red. H. Barycz, Wrocław-Warszawa 1960, s. 210.

${ }^{37}$ L. Hajdukiewicz, Biblioteka Macieja..., nr 210, s. 408 (na górnej okładzinie napis atramentem "Almagestum Ptolemei Doctoris Mechouite").

${ }^{38}$ W. Wydra, op.cit., nr kat. 215. 


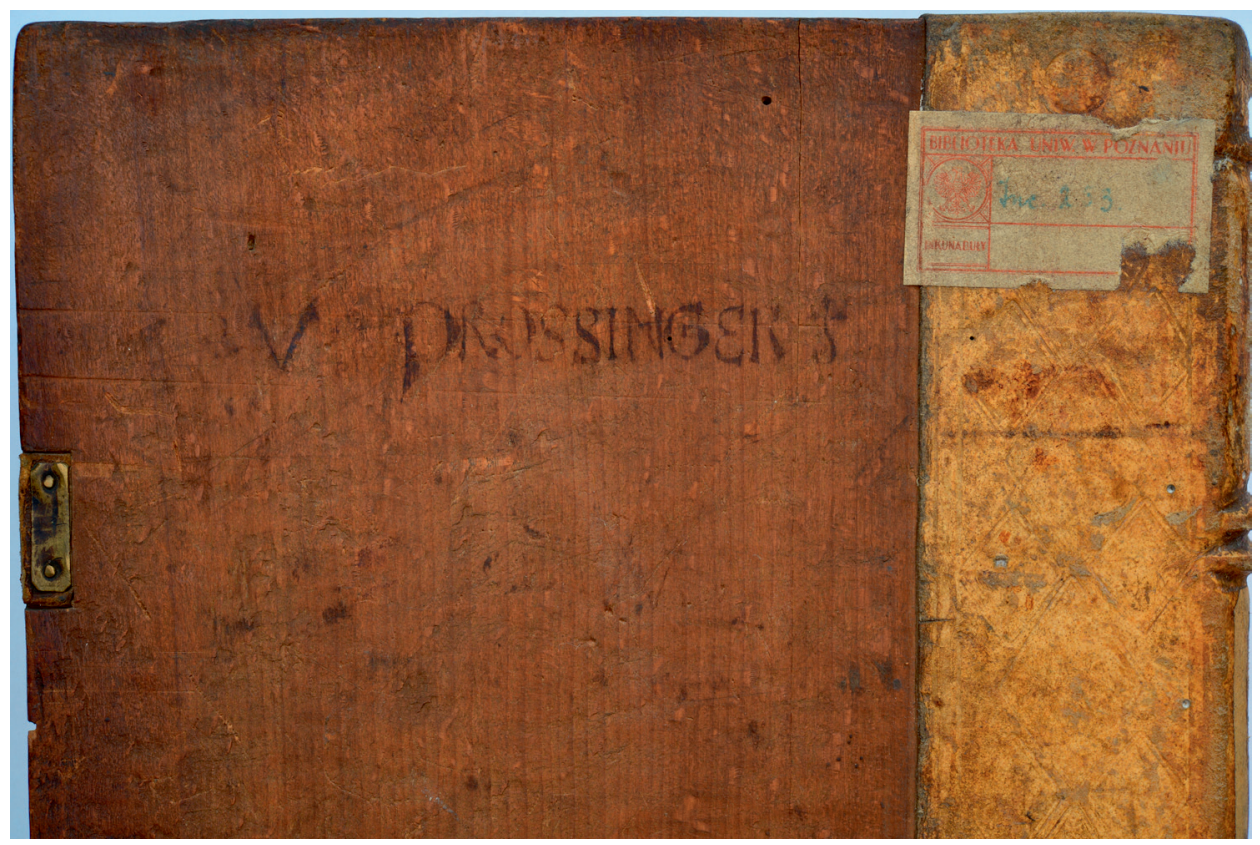

Il. 5. Zapiska własnościowa Ulricha Prossingera na oprawie inkunabułu, Ratyzbona, około 1500

Źródło: zbiory Biblioteki Uniwersyteckiej w Poznaniu.

rem nazwisko właściciela księgi: „V. PROSSINGER”, odznaczające się wczesnorenesansowym krojem majuskułowych liter (il. 5). Ów ratyzboński bibliofil sporządził też na ostatniej karcie księgi notatkę o jej nabyciu: „Liber iste emptus pro 1 pfund pfennig Anno Domini [14]99 die martis Mensis Juny etc. Vlrich Prossinger zw Regenspurg", nie zaniedbując dostojniejszej formy oznaczenia jej własności. Oto bowiem na stronie tytułowej paleotypu zapewne własnoręcznie wykonał on kolorowany rysunek herbu, któremu towarzyszą aż trzy zapiski własnościowe (il. 6). Motyw heraldyczny wyeksponowany został pośrodku stronicy, poniżej wydrukowanego nazwiska autora i tytułu dzieła. Przyciąga on wzrok zarówno starannością opracowania plastycznego, jak i zaakcentowaniem czerwieni barw herbowych. Asymetryczna tarcza, turniejowy hełm typu „żabi pysk" oraz labry fleuronowe w formie postrzępionych liści akantu stanowią o późnogotyckości tego motywu. Pierwsza z zapisek znajduje się nad herbem, prezentując imię i nazwisko właściciela księgi („,Vlricus Prossinger"). Dwie kolejne ulokowano poniżej herbu, przy czym pomimo analogicznej treści są przypuszczalnie autorstwa dwóch różnych rąk. Zastosowany w nich zwrot „Monumenta hec Vdalricj Prossinger etc." nasuwa skojarzenia z formułą stosowaną kilka dekad później na renesansowych 
Il. 6. Ekslibris rysowany i zapiski własnościowe Ulricha Prossingera, Ratyzbona, około 1500 Źródło: zbiory Biblioteki Uniwersyteckiej w Poznaniu.

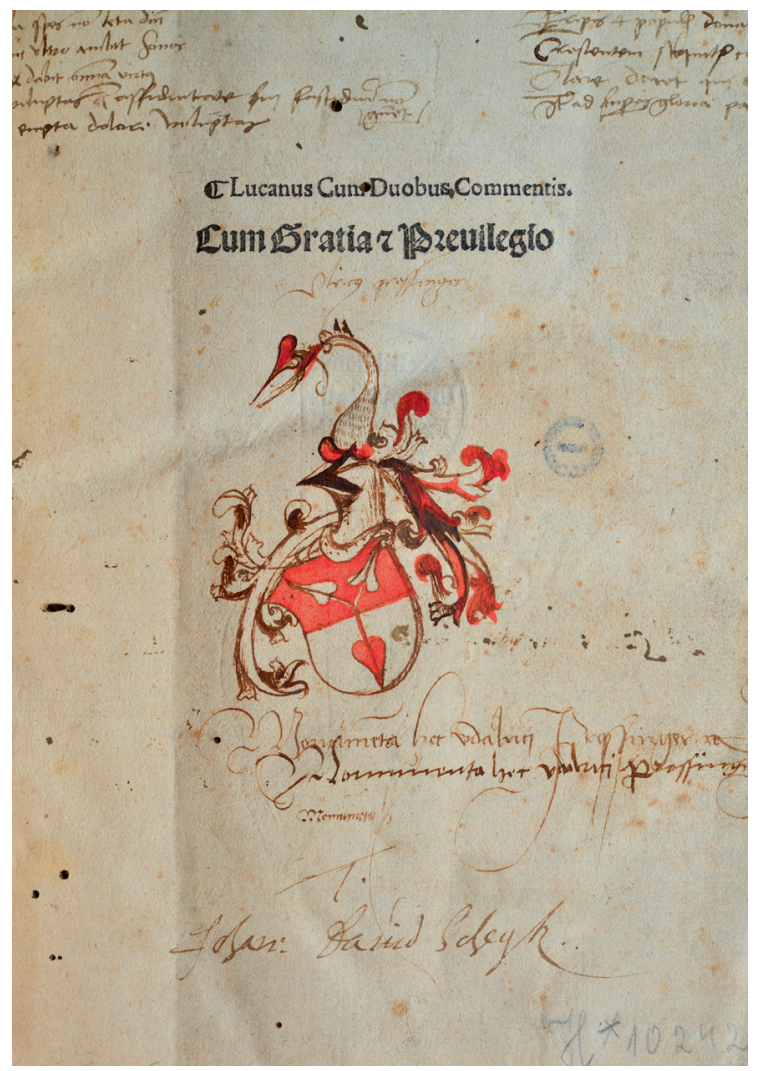

oprawach polskiego króla Zygmunta Augusta ${ }^{39}$, szlachcica Melchiora Krupki $^{40}$ oraz innych bibliofilów ${ }^{41}$. W związku z tym warto nadmienić, że pojęcie "monumentum" vel "monimentum" miało w humanistycznej łacinie przynajmniej dwa znaczenia, wywodzące się z antyku rzymskiego - „pomnik”, „pamiątka, znak pamiątkowy” oraz „księga"42. Wydaje

${ }^{39}$ Por. m.in. M. Krynicka, Oprawy książkowe z herbami ostatnich Jagiellonów w zbiorach Muzeum Narodowego w Krakowie, „Rozprawy i Sprawozdania Muzeum Narodowego w Krakowie" 1980, t. 12, s. 37-38, 40-42, il. 13, 15, 21a, 23, 25.

${ }^{40}$ Por. m.in. K. Komorová, Knižnica významného polského šlachtica a bibliofila 16. storočia Melchiora Krupeka, Praha 2002, s. 9, 31-38, 42-106, il. 8, 11.

${ }^{41}$ M. Mejor (Księgozbiór tańcuchowej biblioteki ze Złotoryi w zbiorach Biblioteki Narodowej, w: Z badań nad dawna ksiażka. Studia ofiarowane Profesor Alodii Kaweckiej-Gryczowej w 85-lecie urodzin, t. 1, red. P. Buchwald-Pelcowa, Warszawa 1991, s. 82, nr 3) opisuje księgę z biblioteki łańcuchowej w Złotoryi - na wewnętrznej stronie górnej okładziny wyciśnięto złocony napis „MONVMENTVM | IOHANNIS: HELMRICI: | 1562”.

42 J. Mączyński, Lexicon latino-polonicum, Regiomontani Borussiae (Królewiec), J. Daubmann, 1564, k. 230 verso: „Monimentum, monimenti, neut. sec. uel ut alij 


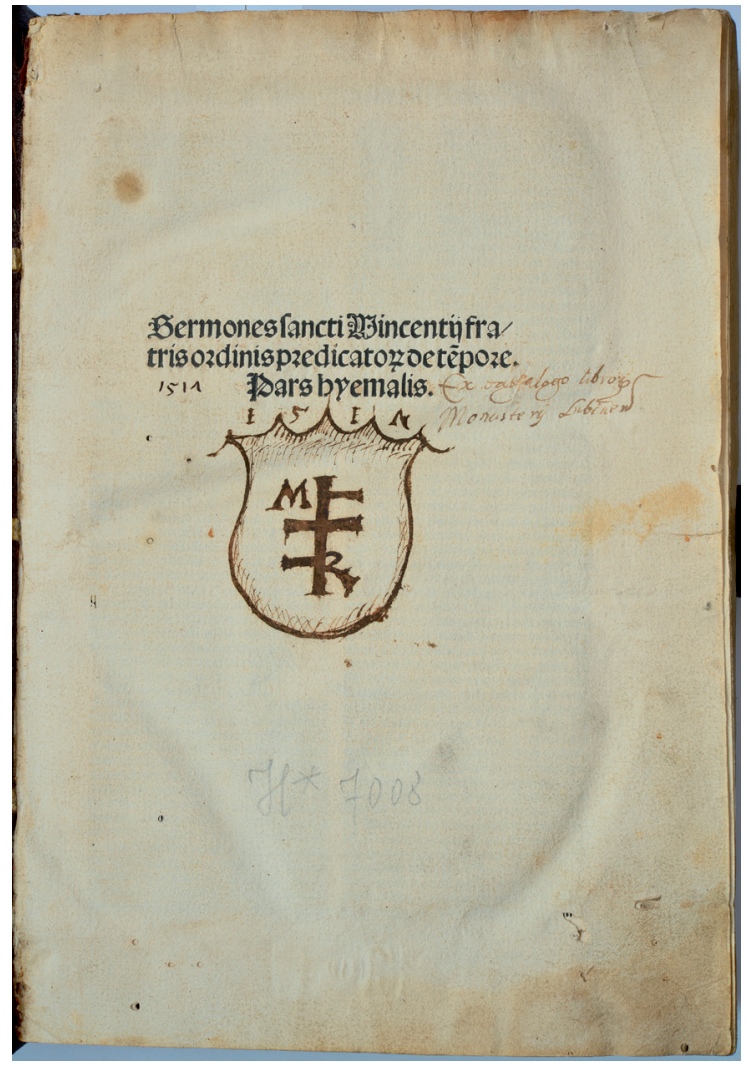

Il. 7. Ekslibris rysowany nieokreślonego szlachcica lub mieszczanina „M R[K?]”, Polska?, 1517

Źródło: zbiory Biblioteki Uniwersyteckiej w Poznaniu.

się jednak, że w odróżnieniu od uniwersalnego i najpowszechniejszego w ówczesnym użyciu pojęcia "liber" słowo „monumentum” miało dostojniejszy wydźwięk. Z pewnością znaczącą rolę odgrywał tu duch cyceroński, wskrzeszany w epoce humanizmu cytatem „Cicero præclara posteritati monumenta reliquit, Cicero známienite upominki potomkom zostáwił / to yest / xięgi które popisał" ${ }^{43}$, co w sferze skojarzeniowej nobi-

uolunt Monumentum per u. Pámiątka/znák pámiątki cziyey / wszeláka rzecz która nas nápomina z czego przeszłego / na to yest grób kámieniem położony / napis / titul / słup / xięgi / etc.”; k. 231 recto: "Monumenta scriptorum, Xięgi”. Z kolei C. Ambrosius (Dictionarium linguae latinae, Basel, Hier. Curio, 1550, s. nienum.) pisze: „Mŏnŭmentŭm [...] dicitur quieqiud nos monet, siue monere potest, quid sit illud, in quod intendimus: ut tituli, sepulchra, statuæ, fama, porticus, carmina, historia, documenta, doctrina, libri [...]". O zastosowaniu tego pojęcia w antyku rzymskim por. C. Ambrosius, op.cit.; J. Kolendo, J. Żelazowski, współpraca E. Bunsch, Teksty i pomniki. Zarys epigrafiki łacińskiej okresu Cesarstwa Rzymskiego, red. J. Kolendo, Warszawa 2003, s. 162.

43 J. Mączyński, op.cit. 
litowało rangę woluminu. W opisanym dziele zastanawiające jest jednak zastosowanie liczby mnogiej wyrazu, ewentualnie nadanie mu końcówki rodzaju żeńskiego, tj. „Monumenta”. Prawdopodobnie zabieg ten miał $\mathrm{w}$ intencji bibliofila akcentować, że oznaczona przez niego księga nie jest jedynym woluminem w jego posiadaniu, ale stanowi cząstkę większego zbioru.

Rysunkowy znak własnościowy na stronicy tytułowej, pod wydrukowanym tytułem widnieje też $\mathrm{w}$ inkunabule Vincentiusa Ferreriusa, Sermones de tempore et de sanctis. P[ars] I, Nürnberg, Antonius Koberger, 1492 (sygn. Inc. 112) ${ }^{44}$. Ma on formę tarczy herbowej o symetrycznym kroju z wklęsłymi wcięciami nasady i delikatnie zacieniowanym obrzeżem (il. 7). W jej polu widnieje nieokreślony gmerk w kształcie krzyża z dwiema poziomymi belkami po heraldycznej lewej oraz - niżej - po prawej stronie. Obok górnej części krzyża wyrysowano antykwowy inicjał „,M”, $\mathrm{u}$ dołu zaś z jego trzonem połączono inicjał „R”, ewentualnie „K". Ponad tarcza, w zagłębieniach wcięć jej nasady zapisano datę „1517”, powtórzoną mniejszymi cyframi z boku tytułu. Na uwagę zasługuje tu wyeksponowanie inicjałów posiadacza księgi w obrębie tarczy, co spotykane było w późnogotyckich i renesansowych księgoznakach i prowadziło niekiedy do zmiany położenia godła herbowego ${ }^{45}$.

W porównaniu z powyższymi dwoma znakami własnościowymi zdecydowanie ciekawsze i - przynajmniej z polskiej perspektywy - cenniejsze są dwa ekslibrisy anonimowego szlachcica „L G” herbu Rawicz wklejone na inkunabułowe strony tytułowe.

Pierwszy z nich widnieje na klocku druków Guillermusa Parisiensisa, Postilla super Epistolas et Evangelia, Strassburg, Georgius Husner, 9 III 1485 (sygn. Inc. 75) i Joannesa Nidera, Praeceptorium divinae legis [...], Strassburg, Georgius Husner, 1483 (sygn. Inc. 76) ${ }^{46}$. Ma kształt prostokątnej karteczki o wymiarach $106 \times 95 \mathrm{~mm}$ z kompozycją drzeworytniczą o wymiarach $93 \times 79$ mm, ukazującą herb Rawicz (Rawa, Niedźwiada, Rawita) z tarczą o symetrycznym, wczesnorenesansowym kroju (il. 8). W jej polu widnieje kroczący niedźwiedź z siedzącą na nim panną z koroną na głowie i rozpostartymi ramionami. Na tarczy osadzony jest hełm prętowy, ujęty na wprost, z którego zwisają fleuronowe labry o symetrycznej kompozycji. Klejnot herbu powtarza motyw niewiasty ujętej od

${ }^{44}$ W. Wydra, op.cit., nr kat. 374.

${ }^{45}$ Zob. np. M. Strutyńska, Katalog inkunabułów Biblioteki Uniwersyteckiej w Toruniu, Toruń 1995, nr kat. 52, 147b, il. 9, 24; B. Gryzio, Muzeum czarnej sztuki. Katalog inkunabułów PAN Biblioteki Gdańskiej, Gdańsk 2012, nr kat. 53 (750), tabl. nienum.

${ }^{46}$ W. Wydra, op.cit., nr kat. 163, 247. 


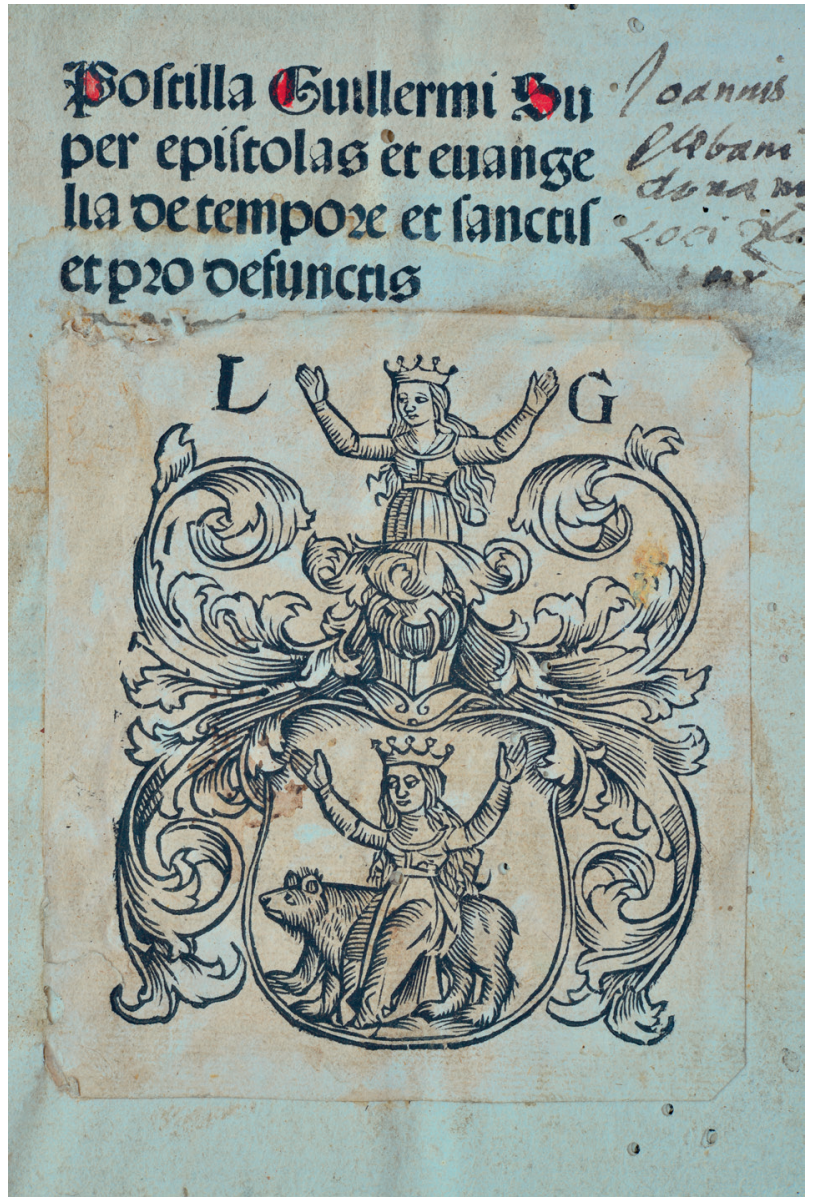

Il. 8. Ekslibris anonimowego szlachcica „L G” herbu Rawicz, artysta anonimowy, drzeworyt, Kraków?, druga dekada, początek trzeciej dekady XVI wieku

Źródło: zbiory Biblioteki Uniwersyteckiej w Poznaniu.

bioder i wyłaniającej się bezpośrednio znad hełmu. Po obu stronach jej ramion znajdują się antykwowe, majuskułowe inicjały "L" i "G", najprawdopodobniej wycięte w tym samym klocku co herb.

O szczególnej pozycji tego dzieła w historii rodzimego ekslibrisu przesądzają jego rzadkość i metryka. Zgodnie bowiem z literaturą przedmiotu jedyny zachowany egzemplarz ekslibrisu znajduje się w Bibliotece Jagiellońskiej w Krakowie, jako rycina wyklejona z tytułowej strony pracy Ludwika Celiusza Rodigina zatytułowanego Lectiones antiquae, wydanego w Paryżu w 1517 roku. Został on opisany po raz pierwszy w 1974 roku przez Annę Lewicką-Kamińską w publikacji poświęconej nieznanym polskim księgoznakom z XVI wieku ${ }^{47}$. Od tego czasu udało się zidentyfikować jeden egzemplarz ekslibrisu znajdujący się w Bibliotece Wyższe-

${ }^{47}$ A. Lewicka-Kamińska, op.cit., s. 13-14, 31, tabl. nienum. 
go Seminarium Duchownego we Włocławku ${ }^{48}$. Wprawdzie w 2002 roku został wzmiankowany egzemplarz poznański w katalogu inkunabułów Biblioteki Uniwersyteckiej, jednak jako dzieło XIX-wieczne, z zastrzeżeniem, że mógł być wykonany wcześniej ${ }^{49}$.

Oba egzemplarze ekslibrisu ze zbiorów włocławskich i poznańskich rzucają nowe światło na kwestię dokładnej daty jego wykonania oraz właściciela. Szczególnie fakt umieszczenia ich w inkunabułach daje podstawę do stwierdzenia, że dzieło to powstało wcześniej, niż przyjęła Lewicka-Kamińska. Badaczka oparła datację krakowskiego egzemplarza ekslibrisu na dacie wykonania oprawy książki, w której się znajdował, uznając go za dzieło z około 1525 roku $^{50}$. Oprawienie księgi w Krakowie skłoniło ją do określenia ekslibrisu jako wytworu krakowskiego, a nawet powiązania go z warsztatem drzeworytniczym "pracującym w tym okresie dla jednej z drukarń krakowskich, prawdopodobnie dla Floriana Unglera" ${ }^{51}$. Swój pogląd wsparła materiałem porównawczym w postaci drzeworytniczych herbów z druków krakowskich ${ }^{52}$. Nietypowość formy klejnotu z ekslibrisu była według uczonej przejawem traktowania tego elementu w heraldyce polskiej jako drugorzędnego, co jednak w świetle współczesnych badań wydaje się dyskusyjne ${ }^{53}$.

Jakkolwiek obecny poziom znajomości dorobku polskich rytowników XVI wieku w zakresie stylistyki oraz ikonografii heraldycznej pozwala na podtrzymanie hipotezy o krakowskim wykonaniu ekslibrisu, to data jego powstania wymaga weryfikacji. Skłania do tego w pierwszej

${ }^{48}$ Wklejony na stronę tytułową inkunabułu - Thomas de Aquino: Scripta ad Hanibaldum episcopum super quattuor libros Sententiarum, Basel, Nic. Kessler, 1498, sygn. B WSD Włocławek XV. F. 1129. Za udostępnienie inkunabułu z ekslibrisem do szczegółowych badań dziękuję dyrektorowi biblioteki, ks. Kazimierzowi Rulce. Zob. też B. Iwańska-Cieślik, Inkunabuły w bibliotece kapituły katedralnej we Włocławku. Zarys problematyki, w: Ksią̇ka w życiu Kościoła, red. T. Kruszewski, Toruń 2009, nr kat. 21.

${ }^{49}$ W. Wydra, op.cit., nr kat. 163.

${ }^{50}$ A. Lewicka-Kamińska, op.cit., s. 13, 31.

${ }^{51}$ Ibidem.

52 Ibidem, s. 13, przypis 34.

${ }^{53}$ Badaczka powołała się na publikację S. Mikuckiego (Barwa w heraldyce średniowiecznej, „Rocznik Polskiego Towarzystwa Heraldycznego we Lwowie” 1928-1929, t. 9, Kraków 1930, s. 219), której przedmiotem są jednak zjawiska wcześniejsze lub przynajmniej kończące się w okresie, na jaki zadatowała ekslibris. Jak podkreśla P. Mrozowski (op.cit., s. 91), klejnot już od XIV wieku był w polskiej heraldyce „ważnym i cenionym symbolem"; J. Szymański (Herbarz rycerstwa polskiego z XVI wieku, Warszawa 2001, s. XVI) twierdzi z kolei, że „do końca XVI w. klejnot upowszechnił się, choć nigdy nie uzyskał charakteru elementu istotnego, bez którego nie mógłby zaistnieć herb". 
kolejności czas wydrukowania ksiąg ozdobionych ekslibrisem - schyłek XV wieku. Także ich oprawy odznaczają się bez wyjątku gotycką strukturą i formą dekoracji, pozwalającymi na ich datowanie na ostatnią ćwierć $\mathrm{XV}$, początek XVI wieku ${ }^{54}$. Wprawdzie znaku wodnego widniejącego na przedniej wyklejce woluminu poznańskiego (głowa wołu, na niej długi krzyż owinięty przez węża, wymiary około $170 \times 40 \mathrm{~mm}$ ) brak w głównych katalogach filigranów europejskich ${ }^{55}$, jednak najbardziej podobne znajdowały się na papierach polskich ze schyłku XV i początku XVI wieku ${ }^{56}$.

Czy zatem i ekslibris można by datować na powyższy okres? Biorąc pod uwagę stan wiedzy o historii polskiej grafiki, wydaje się to mało prawdopodobne. Na ów okres przypada w Polsce schyłek zwyczaju oznaczania kart ksiąg iluminowanymi lub rysowanymi herbami, do których dopiero w drugiej dekadzie XVI wieku doszły ekslibrisy. Wedle obecnego stanu badań pierwszymi z nich były ryciny wykonane w 1516, a następnie w 1517 roku dla biskupa Macieja Drzewickiego. Pierwsza jest właściwie graficzno-drukarskim importem, powstała bowiem w Wiedniu, w warsztacie słynnego impresora, Hieronima Wietora; drugą zaś wykonano w Krakowie na bazie drzeworytniczych ozdobników i czcionek będących w użyciu stołecznych drukarzy: Kaspra Hochfedera, Floriana Unglera, a także Jana Hallera ${ }^{57}$. Okoliczność ta ma zresztą niebagatelne znaczenie $\mathrm{w}$ kontekście podobieństw między omawianym ekslibrisem a zasobem ilustracyjnym krakowskich drukarni w drugim i trzecim

${ }^{54}$ Dekoracja oprawy ze zbiorów poznańskich: na brązowej skórze okładzin kompozycja ramowa ze zwierciadłem wypełnionym wzorem rombowym; w ramie i zwierciadle wyciski trzech łłoków z motywem rozetki, rombu z nieokreślonym zwierzęciem i kwiatonu; jej opis zob. w: W. Wydra, op.cit., nr kat. 75. Dekoracja oprawy ze zbiorów włocławskich: na jasnej skórze okładzin kompozycja ramowa ze zwierciadłem wypełnionym wzorem owocu granatu vel pędu ruty, w wewnętrznych ramach wyciski z ornamentem floralnym i motywem rozety.

55 Najbliższe formy w: Die Ochsenkopfwasserzeichen, cz. 3, red. G. Piccard, Stuttgart 1966, rys. 145-153, 192-198, 205-210, 215-220.

${ }^{56}$ F. Piekosiński, Wybór znaków wodnych z XV stulecia, z. 1, Kraków 1896, rys. 1089 (1511 rok), 1094 (1489 rok), 1096 (1496 rok), 1105 (1495 rok).

57 Analiza elementów kompozycji obu ekslibrisów - zob. w: K. Piekarski, Przyczynki do dziejów polskiego exlibrisu, „Exlibris” 1924, t. 5, s. 1-4, tabl. I-V. Problem tych dzieł w kontekście polskich ekslibrisów graficzno-typograficznych epoki renesansu zob. A. Wagner, Wdzięczna dtubaninka Krzysztofa Jerominka czyli kilka uwag o kategoryzacji i kryteriach artystyczności w ekslibrisie, "Akapit” 2012, t. 7, s. 142, il. 5; idem, Ekslibris jako dziedzina grafiki w sferze zainteresowań historii sztuki i bibliologii, w: Metodologia, metoda $i$ terminologia grafiki i rysunku. Teoria i praktyka, red. J. Talbierska, Warszawa 2012. 
dziesięcioleciu XVI wieku. Należy podkreślić, że ekslibrisy Drzewickiego zawierają renesansowe motywy architektoniczne, w tym zwłaszcza motyw arkady ${ }^{58}$, wyróżniają się też piękna, renesansową czcionką jaką Wietor posługiwał się w swych drukach. Jednakże kształt tarczy w obu ekslibrisach wpisuje się w tradycję późnogotycka, reprezentowaną w Polsce od ostatniej dekady XV wieku tarczami o uspokojonej, symetrycznej formie oraz między innymi ukośnie ściętymi narożami ${ }^{59}$. Klocek drzeworytniczy zawierający motyw tarczy z ekslibrisu Drzewickiego z 1516 roku zastosowano zresztą już wcześniej w książce Johannesa Burcharda, Ordo missae, wydanej w krakowskiej drukarni Floriana Unglera w 1512 roku $^{60}$. Jeśli zatem wziąć pod uwage podobieństwo formy tarczy z ekslibrisu dla „L G” do tarczy z druku Unglerowskiego i ekslibrisu Drzewickiego, to możliwe okazuje się powstanie pierwszego z wymienionych w drugiej dekadzie XVI wieku.

Niestety, mimo dokonanych ustaleń nie znamy wciąż imienia i nazwiska właściciela ekslibrisu. Bibliofil ten nie umieścił bowiem w swoich księgach innych znaków lub wpisów własnościowych. Niewiele w tym zakresie daje również jednoznaczne potwierdzenie znajdowania się w pierwszym inicjale litery „L", a nie „I", jak przypuszczała Lewicka-Kamińska z racji uszkodzenia znanej jej odbitki ${ }^{61}$. Mimo iż bibliofil nadal pozostaje anonimowy, odnalezienie ksiąg w zbiorach położonych daleko od Krakowa oraz ich proweniencje skłaniają do uznania za możliwe, że żył on poza stolicą Korony, a nawet poza Małopolską. Niezależnie od stopnia prawdopodobieństwa powstania anonimowego ekslibrisu kilka lub nawet kilkanaście lat wcześniej niż wynikałoby z dawniejszych badań, jest on jednym z najwcześniejszych ekslibrisów polskich wykonanych w drugiej dekadzie lub w pierwszych latach trzeciej dekady XVI wieku.

Nieznany literaturze, unikatowy ekslibris najprawdopodobniej tego samego właściciela wklejony jest $\mathrm{u}$ dołu strony tytułowej dzieła Hemmerlina Felixa, De nobilitate et rusticitate dialogus et alia opuscula, Strassburg, Ioannes Prüss, ca 1493-1500 (sygn. Inc. 193) ${ }^{62}$. Jest to drzeworyt obcięty przy granicach kompozycji (wymiary: $52 \times 55 \mathrm{~mm}$ - karteczka, $51 \times 54 \mathrm{~mm}-$

58 Problem arkady w ekslibrisie renesansowym - por. A. Wagner, Unbekanntes Silesianum von der Wende des 16. zum 17. Jh. - Exlibris Georgs III oder Georgs IV Henckel von Donnersmarck, „DEG Jahrbuch. Exlibriskunst und Graphik” 2005, s. 5-14, il. 1, 5-7.

${ }^{59}$ P. Mrozowski, op.cit., s. 88, tabl. VI, il. 5-6, tabl. X, il. 4.

${ }^{60}$ K. Piekarski, op.cit., s. 2, tabl. III.

${ }^{61}$ A. Lewicka-Kamińska, op.cit., s. 13.

${ }^{62}$ W. Wydra, op.cit., nr kat. 167, tamże określenie ryciny ekslibrisem z inicjałami ,L $\mathrm{G}^{\prime \prime}$. 


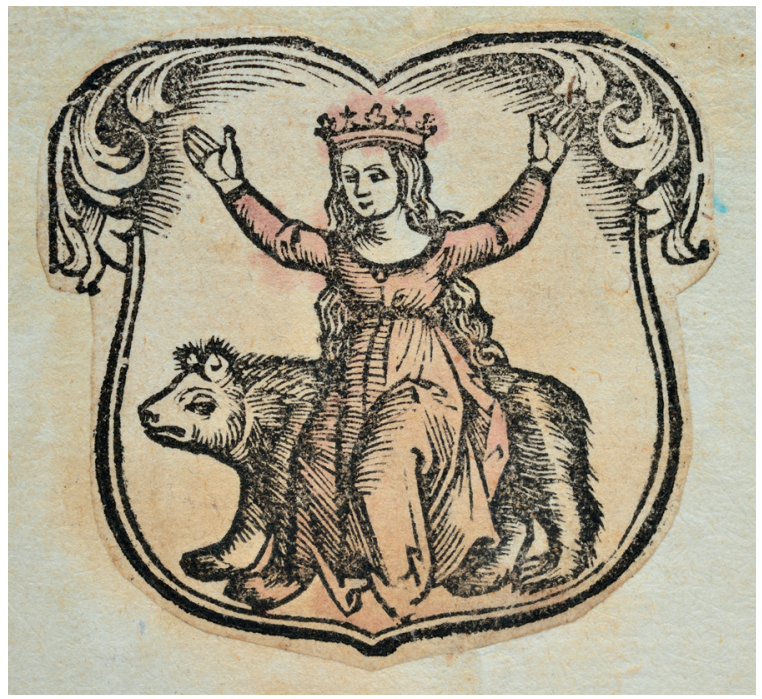

Il. 9. Ekslibris anonimowego szlachcica „L G” herbu Rawicz, artysta anonimowy, drzeworyt kolorowany, Kraków, prawdopodobnie 1523

Źródło: zbiory Biblioteki Uniwersyteckiej w Poznaniu.

odbitka), ukazujący tarczę herbową o analogicznym kształcie i niemal analogicznych wymiarach do tych w poprzednim dziele, jednak z zaakcentowanym szpicem (il. 9). Godło herbu przedstawia w białym polu kroczącego niedźwiedzia z siedzącą na nim panną z koroną na głowie i rozpostartymi ramionami. Jej szatę i koronę pokolorowano na czerwono (obecnie kolor jest wyblaknięty i rozmyty), co przynajmniej w odniesieniu do szaty odpowiada przyjętemu już w XV wieku układowi barw rzeczonego herbu ${ }^{63}$. Sposób opracowania ryciny zdradza znacznie lepszego artystę niż w poprzednim ekslibrisie. Świadczą o tym: większy realizm, plastyczny modelunek światłocieniowy oparty na licznych i delikatnych szrafowaniach, a także precyzja odwzorowania detali anatomicznych (twarz kobiety, głowa zwierza). Powtarzają się w nim jednak przerysowania anatomiczne, zwłaszcza w wielkości głowy względem tułowia. Stanowić to może efekt niedoskonałości warsztatowych drzeworytnika i dostosowania się do obowiązującej w jego czasach heraldycznej konwencji przedstawieniowej tudzież potrzeby zachowania czytelności motywu głowy w miniaturowej pracy.

Dzieło to stanowi jeden z przykładów podwójnego - bibliofilskiego i drukarskiego - wykorzystania tej samej kompozycji graficznej, znanego z kilku innych XVI- i XVII-wiecznych ekslibrisów polskich ${ }^{64}$. Dowodzi

${ }^{63}$ Zob. np. J. Łojko, Średniowieczne herby polskie, Poznań 1985, s. 47; J. Szymański (op.cit., s. 249, il. na s. 258) pisze o szacie czerwonej i koronie złotej.

${ }^{64}$ K. Piekarski, op.cit., s. 1-7, tabl. I-IV, VI; E. Chwalewik, Exlibrisy polskie szesnastego i siedemnastego wieku, Wrocław 1955, s. 14-15, 48-49, il. 8-9, 19; A. Wagner, Ekslibris jako dziedzina grafiki... 
tego unikatowy egzemplarz druku zachowanego w Bibliotece Uniwersyteckiej we Lwowie: Donat (Donatus), Dialogus iuvenibus scholaribus perutissimus, współwydany z: Stanislaus que pars? w krakowskiej oficynie Floriana Unglera w 1523 roku $^{65}$. Odznacza się on nadzwyczaj bogatą szatą edytorska, składającą się głównie z listew drzeworytniczych wypełnionych renesansowymi ornamentami oraz herbami polskich dostojników kościelnych z początków XVI wieku (m.in. prymasa Jana Łaskiego, biskupa Jana Lubrańskiego i biskupa Erazma Ciołka). Na przedostatniej karcie księgi (45 recto), w dolnym narożniku stronicy, z którym sąsiadują listwy ornamentalne, odbito drzeworyt $\mathrm{z}$ tego samego klocka co w omawianym ekslibrisie. Jedyna, ale znacząca, różnica polega na zastosowaniu w nim niemal kwadratowej, linearnej ramki otaczającej herb. Analiza reprodukcji tegoż drzeworytu, zamieszczonej w artykule Henryka Bułhaka, wskazuje, że wykonano go ze zużytego klocka, o czym świadczą wyszczerbienia ramki w jej prawym górnym narożniku ${ }^{66}$. Jeden $z$ ubytków styka się bezpośrednio z górnym konturem tarczy herbowej, inny zaś znajduje się obok prawego (heraldycznie lewego) konturu tarczy. W ekslibrisie nie tylko nie ma już ramki, ale też $\mathrm{w}$ zewnętrznym konturze tarczy - w miejscu, w którym przebiegać winna linia ramki - jest niewielki ubytek. Oznacza to, że ekslibris wykonany został później niż odbitka w druku, prawdopodobnie po uprzednim pozbyciu się (to znaczy wycięciu lub wyłamaniu) cienkich, obwodowych linii kompozycji. Tym samym uprawnione jest zadatowanie go na rok 1523 lub nieznacznie późniejszy okres.

Niestety, w znanych piszącemu te słowa fragmentach treści książki brak informacji o właścicielu herbu, a pośrednio również ekslibrisu. Jest jednak wysoce prawdopodobne, że był on tożsamy z anonimowym bibliofilem "L G". Trudno bowiem wyobrazić sobie, by pomiędzy drugą połową drugiej dekady XVI wieku a 1523 rokiem żyło w kręgach szlacheckich dwóch Rawinitów będących bibliofilami, mających upodobanie w nowatorskiej koncepcji oznaczania ksiąg i w dodatku w zbliżonej formie plastycznej. Istnieje zatem podstawa do wysunięcia hipotezy, że dzieło to wykonano po drzeworycie $z$ inicjałami, mimo że i tu forma kompozycji jest jeszcze późnogotycka (zwłaszcza ostro łamane fałdowania sukni). Wedle takiego założenia ekslibris ów zastąpił starszy i artystycznie gorszy znak własnościowy. Kiedy to nastąpiło? Zważywszy na formalno-stylowe pokrewieństwo obu dzieł, możliwe jest, że krótko -

65 H. Bułhak, Miscellanea Bibliographica. Druki krakowskie XVI w. Kasper Hochfeder. Jan Haller. Florian Ungler, „Biuletyn Biblioteki Jagiellońskiej”, R. XLVI, 1996, s. 40-43, il. 3-11.

66 Ibidem, s. 42-43, il. 11. 
tj. w ciągu paru lat - po sporządzeniu pierwszego ekslibrisu i ewentualnym wyczerpaniu nakładu jego odbitek. Niewykluczone jednak, że o zmianie ekslibrisu przesądziło uszkodzenie jego klocka w newralgicznym miejscu, jakim jest pierwsza litera inicjałów. O ile bowiem w poznańskim egzemplarzu dzieła litera „L" ma jedynie uszczerbek dolnego szeryfu widoczny pod lupa, o tyle w egzemplarzu krakowskim brakuje znacznej części dolnej belki litery.

Za sprawą zamieszczenia odbitki ryciny w druku Unglerowskim jej wykonawcy należałoby szukać w środowisku krakowskich drzeworytników. Być może ten sam twórca wykonał drzeworytniczy ekslibris Piotra Wedelicjusza z Obornik (lata 20. XVI wieku - 1548), wklejony na stronę tytułową druku ze zbiorów PAN Biblioteki Gdańskiej ${ }^{67}$. Praca ta odznacza się podobieństwem do omawianej ryciny pod względem sposobu opracowania (delikatny modelunek światłocieniowy i szrafirunek tła) oraz zgrabności kompozycji. Jest ograniczona do tarczy herbowej z godłem, bez pozostałych utensyliów i inicjałów, jednak w otoku z renesansowego wieńca. Została też starannie obcięta wzdłuż krawędzi odbitki.

Godny podkreślenia w kontekście opisanych dzieł rysunkowych i graficznych jest fakt ich naniesienia na pierwszą stronę tekstu inkunabułów, tożsamą ze stroną tytułową. Pozwala to na wyciągnięcie ogólniejszych wniosków na temat zwyczajów późnośredniowiecznych bibliofilów w kwestii lokalizacji herbowych znaków własnościowych w książkach.

Praktyka umieszczania iluminowanych herbów właścicieli bądź fundatorów głównie w obrębie marginesów pierwszych stron tekstu w średniowiecznych manuskryptach wiązała się z ich strukturą introligatorską i treściową. Były to bowiem pierwsze stronice książki ukazujące się oczom czytelnika po przekartkowaniu wyklejki, karty ochronnej tudzież antefolium, pełniących funkcje czysto praktyczne. Ponadto, z racji nadawania tym stronicom reprezentacyjnej, iluminatorskiej formy były one niejako predestynowane do ekspozycji herbu, w odróżnieniu od poprzedzających je, skromnych kart pergaminowych lub papierowych (co wszakże nie przeszkadzało niektórym właścicielom ksiąg właśnie na nich umieszczać pokaźnych znaków własnościowych). Zwyczaj ten przeniknął do inkunabułów, w których pierwszy inicjał czy też któraś z części marginesów bywały ozdobione herbem właścicielskim.

Wraz z popularyzowaniem się inkunabułów ze stroną tytułową powierzchnia właśnie tych stronic zaczęła być postrzegana jako od powiednia

67 Ksią̇kowe znaki własnościowe XV-XVIII wieku. Katalog wystawy ze zbiorów Biblioteki Gdańskiej Polskiej Akademii Nauk, Malbork 1998, nr 5, tabl. nienum. 
do umieszczania okazalszych form znaków własnościowych ${ }^{68}$. Naturalnie sprzyjała temu dominacja bieli niezadrukowanego papieru, wzbogacona krótkim i przejrzystym „komunikatem” o zawartości treściowej druku. Lokowanie znaku właściciela księgi bezpośrednio pod wydrukowanym tytułem sprzyjało też manifestacji jego zainteresowań. Znacznie skromniejsze możliwości w tej sferze dawały drzeworytnicze strony tytułowe, upowszechniające się na północy Europy od schyłku XV wieku. Pusta powierzchnia ograniczała się na nich czasem jedynie do marginesów, co skutecznie „wypychało" z tych stronic większe ekslibrisy rysowane i malowane, jak też ekslibrisy graficzne. Wraz z procesem zamierania twórczości iluminatorskiej oraz dynamicznym rozwojem sztuki graficznej na przełomie XV i XVI wieku miało to decydujący wpływ na ukonstytuowanie się graficznego ekslibrisu, dla którego naturalnym podłożem stała się w ciągu XVI stulecia wewnętrzna strona przedniej okładziny, ewentualnie karta przedniej wyklejki. Niekiedy zresztą pierwsza z nich była w całości zaklejana dużoformatowym ekslibrisem graficzno-typograficznym, co potwierdzają renesansowe księgoznaki słynnych bibliofilów, np. biskupa Pawła Speratusa, księcia pruskiego Albrechta Hochenzollerna czy Krzysztofa Szydłowieckiego ${ }^{69}$.

Herbowe znaki własnościowe nie znikły jednak zupełnie z kart druków i rękopisów. Jak dowodzi historia rodzimego bibliofilstwa i bibliotekarstwa, przez cały wiek XVI oznaczano nimi strony tytułowe oraz inne karty wnętrza książki. Zasadniczą różnicą w porównaniu ze zwyczajami średniowiecznymi było częste wykorzystywanie techniki graficznej w dwojaki sposób. Pierwszy z nich polegał na naklejaniu karteczki z odbitką ekslibrisową w pustym miejscu stronicy, co jednak ograniczało się zwykle do starszych, inkunabułowych i postinkunabułowych wolu-

${ }^{68}$ Problem ewolucji form stron tytułowych w inkunabułach - zob. m.in.: M.M. Smith, The title-page, its early development 1460-1510, London 2000; J. Tondel, op.cit., s. 100-105, il. na s. 89, 101, 104-106, 122 i inne; A. Wagner, Potega drzeworytu. Niemiecka grafika ksiażkowa XV-XVI wieku, w: Rewolucje graficzne. Albrecht Dürer i szkoła niemiecka XV-XVI wieku, katalog wystawy w Muzeum Okręowym im. Leona Wyczółkowskiego w Bydgoszczy, Bydgoszcz 2011, s. 022, nr. kat./il. 4.

${ }^{69}$ Zob. m.in. E. Chwalewik, op.cit., s. 22, 28, il. 20, 24; T.В. Гребенюк, Владельческие книжные знаки в Отделе редких книг Российской государственной библиотеки, I, Москва 2010, nr kat./il. 64.1-64.4. Na wzmiankowanie zasługuje też nieznane vratislavianum odkryte niedawno w Bibliotece Seminarium Duchownego „Hosianum” w Olsztynie: ekslibris Paula Oberstaina z 1528 roku, odbity i ręcznie kolorowany na planszy o wymiarach $276 \times 198$ mm (kompozycja: $238 \times 117 \mathrm{~mm}$ ), zajmującej całą powierzchnię wewnętrznej strony przedniej okładziny; zob. J. Wojtkowski, Katalog druków XVI wieku Biblioteki Wyższego Seminarium Duchownego Metropolii Warmińskiej "Hosianum” w Olsztynie, Lublin 2012, nr 1181; A. Wagner, Ekslibris jako dziedzina grafiki..., il. 3. 
minów ${ }^{70}$. Drugim zaś było odbijanie drzeworytniczego klocka z opracowaną kompozycją bezpośrednio na karcie książki. W takim wypadku po każdorazowym pokryciu klocka farbą drukarską właściciel księgi bądź też wyznaczony librarius przyciskał go do wybranego fragmentu stronicy, dzięki czemu powstawał znak własnościowy łączący cechy ekslibrisu i rozpowszechnionej w późniejszych epokach - pieczątki. Z tradycją ekslibrisów łączyło się głównie zastosowanie techniki drzeworytniczej oraz w niektórych przypadkach konwencji przedstawieniowej herbu, bliższej powstającym ówcześnie grafikom aniżeli pieczęciom kancelaryjnym lub sygnetom pieczętnym. Odbijanie takich kompozycji nie na osobnej karteczce, ale wprost na kartach księgi, niekiedy z częściowym nachodzeniem na tekst było już jednak analogiczne do czynności odbijania pieczątki. Najprawdopodobniej zresztą czynność tę wykonywano ręką, w której trzymano klocek (w przypadku mniejszych kompozycji zapewne miał on specjalny uchwyt) i którą przyciskano go do wybranego miejsca. Na gruncie polskim takimi dziełami były między innymi ekslibrisy biskupa Andrzeja Krzyckiego (1522-1527), biskupa Pawła Holszańskiego (około 1533), Piotra Izdbieńskiego (przed 1528), Wojciecha Strzałkowskiego (1519-1520), Achillesa Pirminiusa Gassera (1539) i Ferenca Ostrowskiego (około 1583) ${ }^{71}$. Wspomniany ekslibris Jana Dantyszka odbito trzykrotnie na kartach przynajmniej jednej księgi wzmiankowanej przez Edwarda Chwalewika72, zaś w małoformatowym egzemplarzu „aldyna” ze zbiorów ukraińskich - na dolnej połowie strony tytułowej ${ }^{73}$. Najlepiej znany i najczęściej spotykany jest jednak ekslibris (określany też jako pieczątka) prymasa Stanisława Karnkowskiego, sporządzony w drewnie bądź $\mathrm{w}$ metalu ${ }^{74}$. W Bibliotece Uniwersyteckiej znajduje się inkunabuł ozna-

${ }^{70}$ Oprócz wspomnianego wyżej ekslibrisu Piotra Wedelicjusza z Obornik także na przykład ekslibris Biblioteki Senatu Gdańskiego z 1596 roku, wklejony na stronę tytułową inkunabułu (zob. B. Gryzio, op.cit., nr kat. 8 (704), tabl. nienum.).

${ }^{71}$ L. Dobrzyńska-Rybicka, op.cit., s. 10, il. 12; E. Chwalewik, op.cit., s. 18, 16, il. 13, 21; A. Lewicka-Kamińska, op.cit., s. 14-17, 26, 29, il. nienum.; V.E. Vengris, Lithuanian Bookplates, Chicago-Illinois 1980, s. 17, il. 6.

72 E. Chwalewik, op.cit., s. 25.

${ }^{73}$ M. Shamrai, Aldines in libraries of Ukraine. Catalogue, oprac. M. Spandowski, Warsaw 2012, nr kat. 9, tabl. I.

${ }^{74}$ Wśród bogatej literatury dotyczącej ekslibrisu biskupa Karnkowskiego zob. m.in.: E. Chwalewik, op.cit., s. 35, il. 12; S. Rybant, Superekslibrisy prymasa Stanistawa Karnkowskiego w Bibliotece Uniwersyteckiej w Warszawie, w: Z badań nad polskimi księgozbiorami historycznymi. Pogranicza, Warszawa 1991, s. 5-26, il. 1-8 (tamże bogata bibliografia tematu, polemika z wcześniejszymi poglądami i teza o wykonaniu ekslibrisu w metalu); idem, Księgozbiór prymasa Stanisława Karnkowskiego. Źródło badań nad kultura umysłowa dostojnika kościelnego XVI w., w: Z badań nad polskimi księgozbiorami 
Il. 10. Ekslibris (pieczątka?) prymasa Stanisława Karnkowskiego, artysta anonimowy, drzeworyt (pieczątka z metalowego stempla?), po 1582

Źródło: zbiory Biblioteki Uniwersyteckiej w Poznaniu.

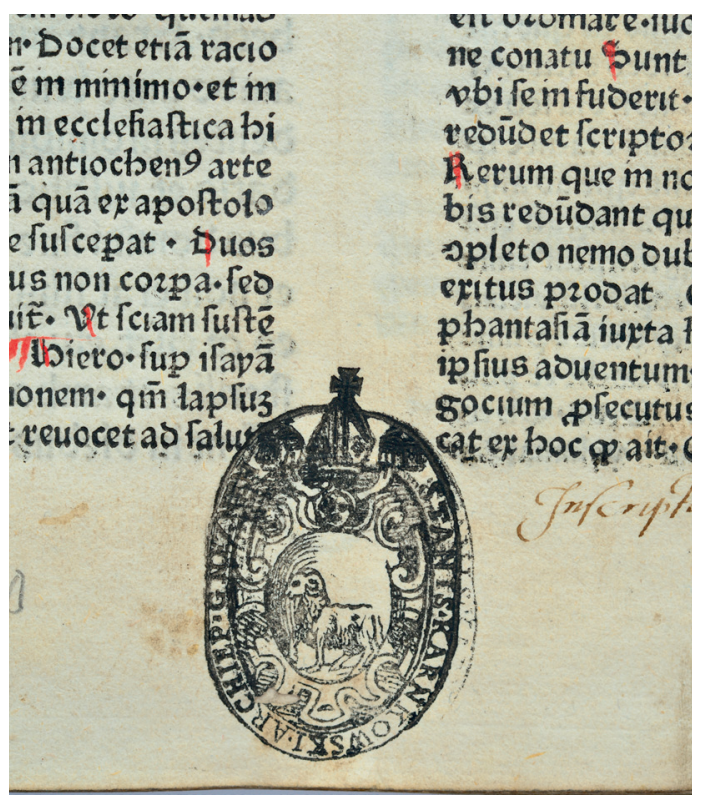

czony takim księgoznakiem, widniejącym pośrodku dolnego marginesu pierwszej strony tekstu (il. 10) ${ }^{75}$. Wyróżniającą się cechą jego odbitki jest dwukrotne, niedbałe przyłożenie klocka (ewentualnie metalowego stempla) do papieru, wskutek czego powstało częściowe zdublowanie napisu i motywu kartusza herbowego. Ponadto wykonano ją z lekko wyeksploatowanego klocka, z odłamanym fragmentem obwodu tarczy oraz uda i ogona zwierzęcia. Styl dekoracji tego dzieła, jak również czas jego powstania sięgają już jednak manieryzmu, co zmusza do odłożenia jego analizy na inną okazję.

Jednym z wyróżników zbioru inkunabułów w Bibliotece Uniwersyteckiej w Poznaniu jest nadzwyczaj interesujący zestaw znaków własnościowych książki z drugiej połowy XV i pierwszej ćwierci XVI wieku, reprezentujących styl późnogotycki oraz przełom gotyku i renesansu. Typologicznie najwcześniejszy wśród nich - protoekslibris (ekslibris malowany) nieokreślonego szlachcica zachodnioeuropejskiego - wkomponowany został w inicjał na początku drukowanego tekstu. Wpisuje się to $\mathrm{w}$ długą, średniowieczną tradycję, której rozpowszechnienie przypada na XIV i XV wiek, a która wraz z nastaniem ery książki drukowanej, od drugiej połowy XV wieku, stopniowo zanikała. Także rzadki egzemplarz

historycznymi. Kolekcje wyznaniowe, Warszawa 1992, s. 122-124 (tamże mowa o odlewie z metalu); A. Wagner, Ekslibris jako dziedzina grafiki...

${ }^{75}$ W. Wydra, op.cit, nr kat. 338. 
tzw. superekslibrisu zapięciowego, wygrawerowanego na mosiężnym zaczepie zapięcia oprawy, należy do kategorii znaków własnościowych, których popularność zawężała się do jednego miasta w Niemczech od schyłku XV do pierwszej połowy XVI wieku, a które po tym okresie zupełnie zanikły. Za ewenement $\mathrm{w}$ rodzimych zbiorach bibliotecznych należałoby uznać model rysunkowy ołtarza szafiastego, który opatrzony herbem i imieniem fundatora posłużył jako ozdoba, przedmiot osobistej dewocji, a przypuszczalnie też znak własnościowy księgi.

Poznańskie paleotypy oznaczone są również znakami własnościowymi, których ogólna forma i lokalizacja w obrębie woluminów znalazły kontynuację nie tylko w renesansie, ale i w kolejnych stuleciach. Należą do nich nazwiska właścicieli ksiąg odręcznie zapisane lub też wykaligrafowane na okładzinach opraw. Koncepcja zarówno ich wyeksponowania na górnej lub dolnej okładzinie, jak i nadania im formy napisu rozkwitła $\mathrm{w}$ epoce renesansu na niezliczonych oprawach w całej łacińskiej Europie - z Polską włącznie - podlegając wszakże głębokim przeobrażeniom technicznym i formalnym. Proces rozwojowy dostrzegalny jest również w heraldyczno-napisowych znakach własnościowych, które znalazły się na inkunabułowych stronach tytułowych. Dwa z nich wykonano jeszcze jako rysunki, wzbogacone kolorowaniem elementów heraldycznych, uzupełnione stosownymi napisami identyfikacyjnymi. Kolejne mają już postać drzeworytniczej grafiki. Odzwierciadla się w tym charakterystyczny dla przełomu XV i XVI wieku proces wypierania tradycyjnych form oznaczania i zarazem zdobienia wnętrza ksiąg przez ekslibrisy graficzne. Dwa ekslibrisy anonima „L G” herbu Rawicz zasługują na tym bliższą uwagę, że stanowią dokładnie połowę wszystkich znanych obecnie księgoznaków tego bibliofila, jeden $\mathrm{z}$ nich jest zaś absolutnym unikatem. Wszystkie należą do grupy najstarszych ekslibrisów polskich powstałych w drugiej lub trzeciej dekadzie XVI wieku. 


\title{
Some remarks on the private marks of ownership of books from the latter half of the fifteenth century and the first decades of the sixteenth century in the incunabula kept at Poznan University Library
}

\begin{abstract}
Aвstract. This article reports on a set of remarks on the characteristic types of private ownership marks that are to be fund in the incunabula currently held in the collection of old and rare books at Poznań University Library. The marks of ownership are analyzed and positioned against the cultural phenomena of the late Middle Ages and early decades of Renaissance in Europe and Poland. First, the hand-painted bookplate (the earliest form of book plates) is discussed. This analysis is then followed by descriptions of the sketched altar model (bookplate depicting an altar) with the coat-of-arms of the donator pasted into a book as an object of devotion and, presumably, a proper mark of ownership, then the so-called clasp hasp bookplate (in German language: Schließen-Exlibris), placed on the hasp of the clasp on the binding. Finally, names inscribed on the inside front cover of a book that indicated its owner or owners, and individual family crests placed on title pages are discussed. Separate attention is given to graphical bookplates, in particular to unique pieces of ornamentation that relate to the anonymous book collector with the exhibited noble Rawicz coat of arms, as well as to book plates imprinted directly onto pages of books.
\end{abstract}

KEY wORDS: painted bookplate, earliest bookplates, altar model, ownership inscription (note), clasp book plate - Schließen-Exlibris, libraria, monumentum, crest, family coat of arms, graphical bookplate, Anonymous "L G" of the Rawicz family coat of arms, Piotr Wedelicjusz of Oborniki, primate Stanisław Karnkowski. 
